\title{
Facile Synthesis, Characterization, and Antimicrobial Evaluation of Novel Heterocycles, Schiff Bases, and $N$-Nucleosides Bearing Phthalazine Moiety
}

\author{
Mohamed Emad Azab,* Sameh Ahmed Rizk, and Naglaa Fawzy Mahmoud \\ Chemistry Department, Faculty of Science, Ain Shams University; Abbassia, Cairo 11556, Egypt. \\ Received December 11, 2015; accepted January 20, 2016
}

\begin{abstract}
The present work describes convenient synthesis of the novel Schiff bases 5a and b by reacting phthalazinones 4a and b with 4-methoxybenzaldehyde Reaction of the Schiff bases with phenylisothiocyanate afforded diazetidine derivatives $7 a$ and $b$. Also, compounds $4 a$ and $b$ reacted with 2-bromoglucoside tetraacetate giving peracetylated $\mathrm{N}$-glycosides $6 \mathrm{a}$ and $\mathrm{b}$, which were deacetylated to afford $\mathrm{N}$-glycosylated phthalazinones $8 \mathrm{a}$ and $\mathrm{b}$. On the other hand, when compound 3 was treated with $\mathrm{POCl}_{3} / \mathrm{PCl}_{5}$ and/or ethyl chloroacetate, chlorophthalazine and ethyl acetate derivatives 9 and 10 were obtained, respectively. Hydrazinolysis of compounds 9 and 10 produced the hydrazino and hydrazide derivatives 11 and 12, respectively. When compound 11 reacted with 2-furanaldehyde, acetic anhydride, and/or carbon disulphide, it gave compounds 13-15, respectively. Treatment of the hydrazide 12 with aromatic aldehydes, acetic anhydride, ethyl acetoacetate, acetyl acetone, ammonium thiocyanate, and/or phthalic anhydride furnished compounds 17-21. Meanwhile, reacting Schiff base 22 with the chlorophthalazine derivative 9 produced compound 23 , which on treatment with furoyl chloride produced compound 24 . The structures of the novel compounds were confirmed by IR, ${ }^{1}$ H-NMR, ${ }^{13} \mathrm{C}-\mathrm{NMR}$, MS, and elemental analysis. The newly synthesized compounds were tested against Bacillus subtilis and Staphylococcus aureus as Gram-positive bacteria, Escherichia coli and Pseudomonas aurignosa as Gram-negative bacteria, and Candida albicans and Aspergillus niger as fungi strains. Compounds $5 a$ and b, 23, and 24 showed greater antimicrobial activity than the stranded compounds, suggesting that they could be considered as promising antimicrobial agents.
\end{abstract}

Key words phthalazin-1-one; $N$-glycosylated phthalazinone; Schiff base; diazetedine; antimicrobial activity

Phthalazines as $N$-heterocycles have received considerable attention in the literature as a consequence of their role as pharmacophore. ${ }^{1,2)}$ Recently, they are derived from a wide range of biologically active natural products, troponoid family. ${ }^{3)}$ A novel series of $N$-substituted-4-phenyl/benzylphthalazin-1-ones, phthalzine-1,4-dione showed antitumor activity. $^{4-7)}$ It is well known that phthalazinone derivatives like other members of isomeric diazine series have considerable biological and pharmaceutical activities. Indeed, several phthalazinone derivatives have been reported to possess antirheumatic, ${ }^{8)}$ antihyperglycemic, ${ }^{9)}$ anticonvulsant, ${ }^{10)}$ antihypertensive, ${ }^{11)}$ antithrombotic, ${ }^{12)}$ antitrypanosoma, ${ }^{13)}$ antioxidant, ${ }^{14)}$ anti-inflammatory ${ }^{15)}$ and $\beta$-adrenergic blocking activities. ${ }^{16)}$ Besides, they can be used as Potent Vasodilators, ${ }^{17)}$ and $\alpha 1$ adrenoceptor antagonists. ${ }^{18)}$ A number of established drug molecules like Hydralazine, ${ }^{19)}$ Azelastine, ${ }^{20)}$ Ponalrestat $^{21)}$ and Zopolrestat $^{22)}$ were prepared from the corresponding phthalazinones. Moreover, many substituted and fused phthalazine and phthalzinone derivatives exhibited antimicrobial activity. $^{23-26)}$

On the basis of the above findings and in continuation of our research interest in the synthesis of novel biologically active heterocycles, ${ }^{27-31)}$ and with the aim of preparing new derivatives of phthalazine with potential pharmacological activity, we report here the synthesis of novel Schiff bases containing phthalazine moiety, phthalazinone and fused phthalazine derivatives, followed by evaluation of their antimicrobial activity against different strains of bacteria and fungi, where most of synthesized compounds exhibited a moderate to a strong antimicrobial activities. Some of the tested compounds showed antimicrobial activity higher than the reference compounds.

\section{Results and Discussion}

Chemistry The reaction of commercially available 2(2-(4-methoxyphenyl)acetyl)benzoic acid (1) with hydroxyl amine and/or hydrazine hydrate, afforded 4-(4-methoxybenzyl)-1H-benzo[d][1,2]oxazin-1-one $(2)^{32)}$ and phthalazinone derivative $3,^{33,34)}$ respectively. Treatment of $\mathbf{2}$ with binucleophiles e.g., 1,4-phenylenediamine and 4,4'-diaminobiphenyl afforded the $N$-substituted phthalazinone derivatives $4 \mathbf{a}$ and $\mathbf{b}$, respectively (Chart 1).

Compounds $4 \mathbf{a}$ and $\mathbf{b}$ may be formed through the nucleophilic attack of the amino group (of the diamine) on the carbonyl group of benzoxazine causing ring opening followed by elimination of water molecule and ring closure. The structure of these compounds were elucidated depending on their IR spectra which displayed peaks in the region 3348-3283 attributable to $\mathrm{NH}_{2}$ groups, and ${ }^{1} \mathrm{H}-\mathrm{NMR}$ which showed signals at $\delta 6.39$ (s, 2H, $\mathrm{NH}_{2}, \mathrm{D}_{2} \mathrm{O}$ exchangeable) for $\mathbf{4 a}$ and 6.23 (s, $2 \mathrm{H}$, $\mathrm{NH}_{2}, \mathrm{D}_{2} \mathrm{O}$ exchangeable) for $\mathbf{4 b}$, respectively.

When compounds $\mathbf{4 a}$ and $\mathbf{b}$ were refluxed with 4-methoxybenzaladehyde in absolute ethanol and/or 2-bromo-2deoxy-1,3,4,6-tetra- $O$-acetyl- $\alpha$-D-glucopyranose in dioxane, ${ }^{35}$ the Schiff bases $\mathbf{5 a}$ and $\mathbf{b}$ and the $N$ - $\alpha$-D-glucosetetraacetate phthalazinone derivatives $\mathbf{6 a}$ and $\mathbf{b}$ were obtained, respectively, in a good yield (Chart 2).

Formation of the Schiff bases $\mathbf{5} \mathbf{a}$ and $\mathbf{b}$ occurs through the nucleophilic attack of the amino on the carbonyl group of the aldehyde followed by elimination of water molecule. The IR 
spectra of $\mathbf{5 a}$ and $\mathbf{b}$ devoid any bands for the $\mathrm{NH}_{2}$ group and the mass spectra showed molecular ion peaks at $\mathrm{m} / \mathrm{z} 475$ and 551 , respectively.

The structure of compounds $\mathbf{6 a}$ and $\mathbf{b}$ was confirmed from the IR spectra which showed three peaks in the region 1660-1685 attributable to three $\mathrm{C}=\mathrm{O}$ groups of phthalazinone and peracetyl moieties, respectively. Also, their ${ }^{1} \mathrm{H}-\mathrm{NMR}$ spectra displayed signals at $\delta 2.08-2.29\left(\mathrm{~s}, 12 \mathrm{H}, 4 \mathrm{COCH}_{3}\right)$, and $2.05-2.24\left(\mathrm{~s}, 12 \mathrm{H}, 4 \mathrm{COCH}_{3}\right)$, respectively.

When the Schiff bases $\mathbf{5 a}$ and $\mathbf{b}$ were allowed to react with phenylisothiocyanate, diazetidine derivatives $7 \mathbf{a}$ and $\mathbf{b}$ were obtained. The proposed structure $7 \mathbf{a}$ and $\mathbf{b}$ were elucidated from the IR spectra which displayed peaks in the region $1319-1322$ attributable to $\mathrm{C}=\mathrm{S}$ group, ${ }^{1} \mathrm{H}-\mathrm{NMR}$ spectra which showed peaks at $\delta 6.56-6.61$ corresponding to the

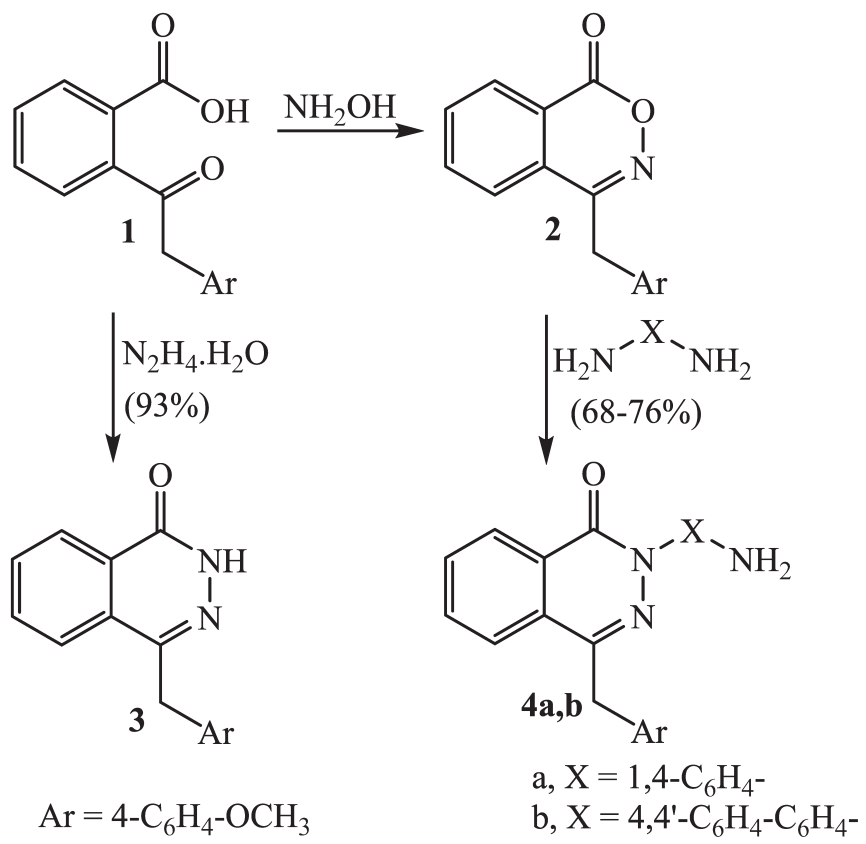

Chart 1 benzylic protons of the diazetidine ring. Also by the mass spectra which showed molecular ion peaks at $\mathrm{m} / \mathrm{z} 610$ and 686 , respectively.

Moreover, the hydrolysis of $\mathbf{6 a}$ and $\mathbf{b}$, using sodium carbonate, afforded the deacetylated glucose phthalazinone derivatives $\mathbf{8 a}$ and $\mathbf{b}^{35)}$ (Chart 2). The structures of $\mathbf{8 a}$ and $\mathbf{b}$ were assigned by their IR spectra which displayed peaks at $v\left(\mathrm{~cm}^{-1}\right)$ 3384-3261 (OH bonded and non-bonded) and mass spectra that showed a molecular ion peaks at $m / z 519$ and 595, respectively.

On the other hand, the phthalazinone derivative $\mathbf{3}$ was subjected to react with a mixture of $\mathrm{POCl}_{3} / \mathrm{PCl}_{5}{ }^{36}$ ) and/or ethyl chloroacetate, in presences of potassium carbonate, ${ }^{34)}$ producing 1-chlorophthalazine and phthalazinone ethyl acetate derivatives $\mathbf{9}$ and $\mathbf{1 0}$, respectively.

The formation of 9 takes place via the reaction of $\mathrm{POCl}_{3} /$ $\mathrm{PCl}_{5}$ with the hydroxyl group of the enol form of compound $\mathbf{3}$. The structure of 9 was indicated from its IR spectrum which devoid any bands for the $\mathrm{C}=\mathrm{O}$ and $\mathrm{NH}$ groups. While the formation of product $\mathbf{1 0}$ is believed to proceed via $S_{N} 2$ mechanism through nucleophilic attack of the lone pair of nitrogen atom on the electronically deficient carbon attached to chlorine atom followed by elimination of $\mathrm{HCl}$ molecule. The structure of $\mathbf{1 0}$ was confirmed as a result of the presence of two absorption bands at 1745,1684 (in the IR spectra) attributable to two $\mathrm{C}=\mathrm{O}$ groups of the ethyl ester and phthalazinone moieties. Also, the ${ }^{1} \mathrm{H}-\mathrm{NMR}$ showed $\delta 1.34\left(\mathrm{t}, 3 \mathrm{H}, \mathrm{CH}_{3}, J=6.1 \mathrm{~Hz}\right)$ and 4.39 (q, $2 \mathrm{H}, \mathrm{CH}_{2}, J=8.2 \mathrm{~Hz}$ ), indicating the presence of ethyl ester group.

When both compounds $\mathbf{9}$ and $\mathbf{1 0}$ were further reacted with hydrazine hydrate in boiling ethanol, the hydrazino phthalazine $^{37)}$ and phthalazinone acetohydrazide ${ }^{34)}$ derivatives 11 and 12 were produced, respectively (Chart 3).

Formation of compound $\mathbf{1 1}$ takes place through nucleophlic attack of hydrazine molecule on the carbon atom (attached to the chlorine atom) followed by elimination of $\mathrm{HCl}$ molecule. The IR spectrum of 11 showed peaks at 3379, 3285, 3147 $\left(\mathrm{NH}_{2}, \mathrm{NH}\right)$.

On the other hand, the hydrazide $\mathbf{1 2}$ is formed via tetrahe-

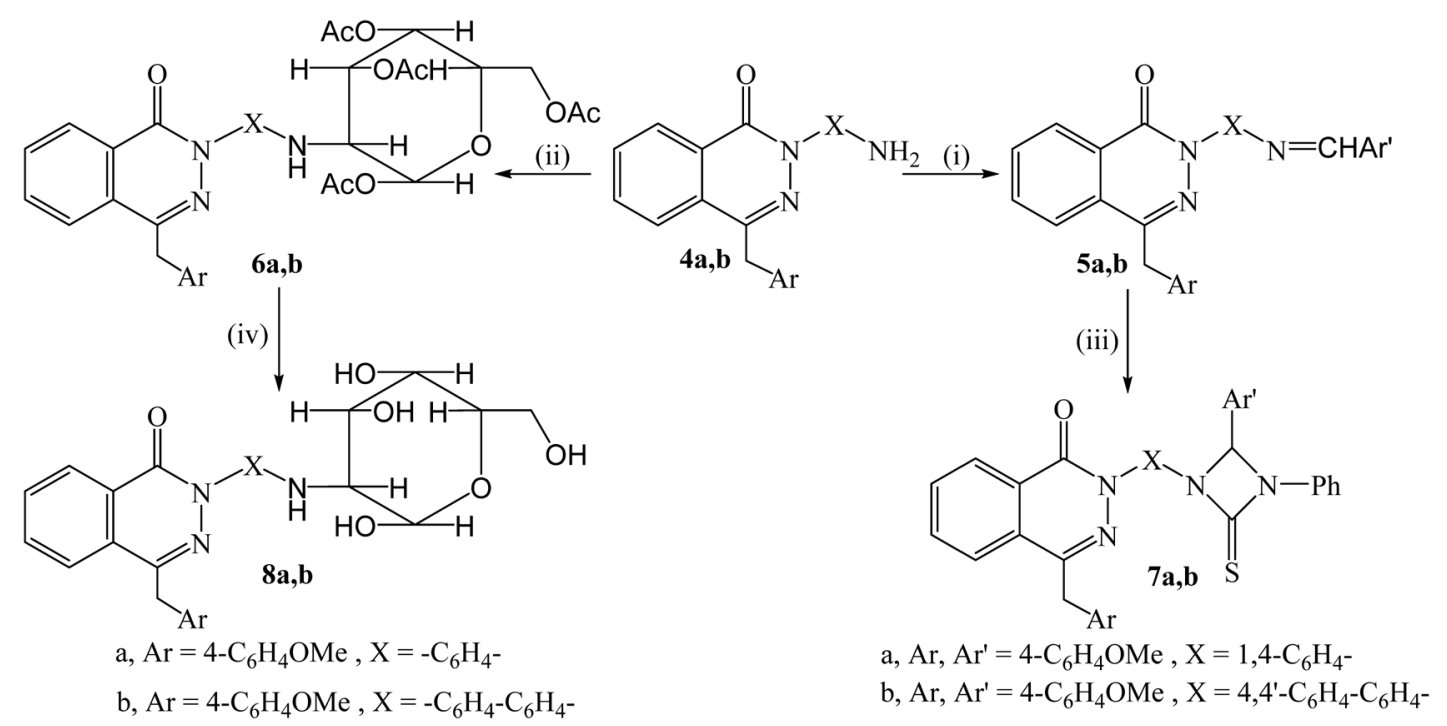

Reagents and conditions: (i) 4-Methoxybenzaldehyde/EtOH/reflux 3h (74-80\%), (ii) 2-bromo-2-deoxy-1,3,4,6-tetra- $O$-acetyl- $\alpha$-D-glucopyranose/dioxane/reflux 4h (56-58\%), (iii) $\mathrm{PhNCS} /$ toluene/reflux/6h (68-72\%), (iv) $\mathrm{Na}_{2} \mathrm{CO}_{3}$ solution/ $\mathrm{MeOH}(43-48 \%)$. 


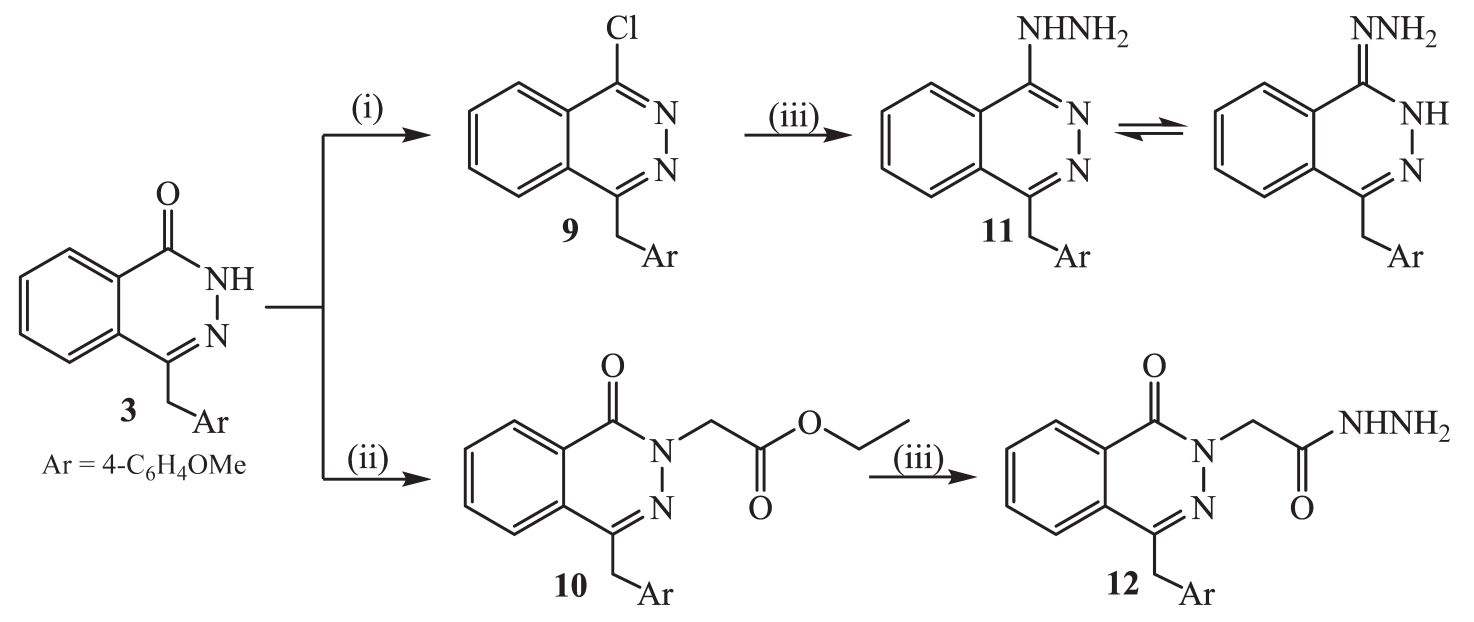

Reagents and conditions: (i) $\mathrm{POCl}_{3} / \mathrm{PCl}_{5} /$ reflux $4 \mathrm{~h}(84 \%)$, (ii) $\mathrm{ClCH}_{2} \mathrm{CO}_{2} \mathrm{C}_{2} \mathrm{H}_{5} / \mathrm{K}_{2} \mathrm{CO}_{3} /$ dry acetone/reflux $24 \mathrm{~h}(80 \%)$, (iii) $\mathrm{N}_{2} \mathrm{H}_{4} \cdot \mathrm{H}_{2} \mathrm{O} / \mathrm{EtOH} / \mathrm{reflux} 3 \mathrm{~h}(85,90 \%$ ).

Chart 3

dral mechanism through the attacking of nucleophilic hydrazine molecule on the $s p^{2}$ carbon of the carbonyl functionality of the ester group in compound $\mathbf{1 0}$ with the elimination of an ethanol molecule. The structure of hydrazide 12 was supported by its spectroscopic data, where the IR spectrum displayed peaks at 3350, 3211, $3130\left(\mathrm{NH}_{2}, \mathrm{NH}\right)$ and the ${ }^{1} \mathrm{H}-\mathrm{NMR}$ indicated the absence of any peaks for the ethyl group.

The 1-hydrazinophthalazine derivative $\mathbf{1 1}$ was used as a key starting material to synthesize different interesting phthalazine and fused phthalazine derivatives. Thus, condensation of 11 with 2-furanaldehyde in boiling ethanol, produced the hydrazone derivative 13. ${ }^{38)}$ While, 1,2,4-triazolo[3,4- $a$ ]-phthalazines 14, and $\mathbf{1 5}$ have been prepared upon the reaction of $\mathbf{1 1}$ with carbon electrophiles namely, acetic anhydride and carbon disulphide, respectively.

Compound $\mathbf{1 3}$ is formed through condensation reaction between the carbonyl group of the aldehyde and the amino group of the hydrazino-derivative. The IR spectrum of $\mathbf{1 3}$ devoid any peaks for the $\mathrm{NH}_{2}$ group, and the ${ }^{1} \mathrm{H}-\mathrm{NMR}$ showed a peak at $\delta 6.39$ for the methine proton $(-\mathrm{N}=\mathrm{CH}-)$.

A plausible explanation for the formation of product 14 consists in acetylation of the hydrazino group followed by 1,3-proton shift, attacking of lone pair of N-1 on the acetyl carbonyl group and finally elimination of a water molecule. The structure was elucidated by the spectroscopic data, where the IR showed the absence of any absorption bands for $\mathrm{NH}$ or $\mathrm{NH}_{2}$, and the ${ }^{1} \mathrm{H}-\mathrm{NMR}$ showed a peak at $\delta 2.44$ (s, 3H), corresponding to the methyl group.

Compound $\mathbf{1 5}$ is possibly formed through the attacking of the nucleophilic amino group on the electronically deficient carbon of carbon disulfide, 1,3-proton shift then attacking of $\mathrm{N}-1$ on $\mathrm{C}=\mathrm{S}$ functionality with the elimination of $\mathrm{H}_{2} \mathrm{~S}$ molecule. The IR spectrum of $\mathbf{1 5}$ showed a peak at $1271(\mathrm{C}=\mathrm{S})$ and devoid any bands for $\mathrm{NH}$ and $\mathrm{NH}_{2}$ groups. Also the ${ }^{1} \mathrm{H}-\mathrm{NMR}$ displayed a peak at $\delta 11.96\left(\mathrm{~s}, 1 \mathrm{H}, \mathrm{D}_{2} \mathrm{O}\right.$ exchangeable) attributable to the $\mathrm{SH}$ group.

Compound $\mathbf{1 5}$ was confirmed chemically via its reaction with hydrazine hydrate to furnish the corresponding hydrazine derivative 16 (Chart 4).

Compound $\mathbf{1 6}$ may take place by the nucleophilic attack of the hydrazine molecule on the carbon atom (bearing the $\mathrm{SH}$ group), followed by elimination of $\mathrm{H}_{2} \mathrm{~S}$ molecule. The structure of $\mathbf{1 6}$ gets support from its spectroscopic data which showed absorption bands $\left(v \mathrm{~cm}^{-1}\right)$ at 3364, 3260, 3174 attributable to both $\mathrm{NH}$ and $\mathrm{NH}_{2}$ and $\delta$ values (ppm) at $5.65(\mathrm{~s}, 2 \mathrm{H}$, $\mathrm{NH}_{2}, \mathrm{D}_{2} \mathrm{O}$ exchangeable) and $11.11\left(\mathrm{~s}, 1 \mathrm{H}, \mathrm{NH}, \mathrm{D}_{2} \mathrm{O}\right.$ exchangeable).

Meanwhile, the hydrazide $\mathbf{1 2}$ could be used as versatile synthon for preparing different hydrazones and building up many ring systems by reacting the hydrazide group with different reagents. Thus, reaction of $\mathbf{1 2}$ with different aldehydes such as furan-2-carboxaldehyde, piperonal and 2-methoxybenzaldehyde, in boiling ethanol, gave the hydrazones $17 \mathbf{a}-\mathbf{c},{ }^{39}$ ) respectively. This reaction takes place through a condensation reaction between the $\mathrm{NH}_{2}$ group of hydrazide $\mathbf{1 2}$ and the carbonyl group of the aldehyde. The structures of hydrazones 17a-c were supported by the their IR spectra which devoid any peaks for the $\mathrm{NH}_{2}$ group, and the ${ }^{1} \mathrm{H}-\mathrm{NMR}$ spectra which displayed peaks at $\delta 6.16-6.31(\mathrm{~s}, 1 \mathrm{H})$ for the methine proton $\mathrm{N}=\mathrm{CH}-$.

Reaction of 12 with acetic anhydride and/or ethyl acetoacetate afforded the 1,3,4-oxadiazole derivatives $\mathbf{1 8 a}$ and $\mathbf{b}$, respectively.

According to our speculation, product 18a is formed through actylation of the hydrazine group of compound 12, 1,3-proton shift followed by cyclization with the elimination of a water molecule. The IR spectrum of this compound devoid any peaks for $\mathrm{NH}$ and $\mathrm{NH}_{2}$ groups and its ${ }^{1} \mathrm{H}-\mathrm{NMR}$ spectrum showed a peak at $\delta 2.55(\mathrm{~s}, 3 \mathrm{H})$ attributable to the methyl group. While compound $\mathbf{1 8 b}$ is believed to be formed through nucleophilic attack of the amino group on the electronically deficient carbonyl carbon of the ester group with elimination of EtOH molecule, 1,3-proton shift and finally cyclization with elimination of water molecule. The structure of $\mathbf{1 8 b}$ was elucidated from its IR spectrum which displayed absorption bands at 1672,1660 for two $\mathrm{C}=\mathrm{O}$ groups, and the ${ }^{1} \mathrm{H}-\mathrm{NMR}$ spectrum which showed peaks at $\delta 2.01(\mathrm{~s}, 3 \mathrm{H})$, for $-\mathrm{COCH}_{3}$ and $3.92(\mathrm{~s}, 2 \mathrm{H})$ for $-\mathrm{CH}_{2}-\mathrm{CO}-$ of the acetonyl group.

On the other hand, treatment of $\mathbf{1 2}$ with acetyl acetone and/ or ammonium thiocyanate in ethanol, produced pyrazole and 1,3,4-triazole derivatives $\mathbf{1 9}$ and $\mathbf{2 0}$, respectively. The 1,3-dioxoisoindoline derivative $\mathbf{2 1}$ was obtained upon fusion of the hydrazide 12 with phthalic anhydride in an oil bath at $170^{\circ} \mathrm{C}$ (Chart 5). 
<smiles>[Al]Cc1nn2c(=S)[nH]nc2c2ccccc12</smiles><smiles>[AlH2]Cc1nn2c(S)nnc2c2ccccc12</smiles>

(iv)<smiles>NNc1nnc2c3ccccc3c(CCBr)nn12</smiles><smiles>NNc1nnc(C[Al])c2ccccc12</smiles><smiles>[C]1C=CC=C1</smiles><smiles>[Al]Cc1nnc(N/N=C/c2ccco2)c2ccccc12</smiles>
$\mathrm{Ar}=4-\mathrm{C}_{6} \mathrm{H}_{4} \mathrm{OMe}$ (ii)<smiles>Cc1nnc2c3ccccc3c(C[Al])nn12</smiles>

Reagents and conditions: (i) 2-Furanaldehyde/EtOH/reflux $3 \mathrm{~h}$ (76\%), (ii) $\mathrm{Ac}_{2} \mathrm{O} / \mathrm{heat} 1 \mathrm{~h}(62 \%)$, (iii) $\mathrm{CS} 2 / \mathrm{KOH} / \mathrm{abs}$. EtOH/reflux $6 \mathrm{~h}\left(60 \%\right.$ ), (iv) $\mathrm{N}_{2} \mathrm{H}_{4} \cdot \mathrm{H}_{2} \mathrm{O} / \mathrm{EtOH} / \mathrm{reflux} 3 \mathrm{~h}$ $(54 \%)$.

Chart 4

Product 19 may be formed as a result of a condensation process between the hydrazide moiety of compound $\mathbf{1 2}$ and a molecule of acetyl acetone followed by cyclization of the lactim form (of the condensation product) with elimination of water molecule. The presence of two bands for two $\mathrm{C}=\mathrm{O}$ groups in the IR spectrum of compound 19 supported its proposed structure. Also, its ${ }^{1} \mathrm{H}-\mathrm{NMR}$ displayed peaks at $\delta$ $2.12(\mathrm{~s}, 3 \mathrm{H})$ for the $\mathrm{COCH}_{3}$ group, $2.79(\mathrm{~s}, 3 \mathrm{H})$ for the methyl group attached to the pyrazole ring and 3.89 (s, 1H, pyrazole).

It is well known that ammonium thiocyanate isomerizes to thiourea under the effect of heat. ${ }^{40)}$ So, the mercaptotriazole 20 could be obtained from the attacking of thiourea on the carbonyl of the hydrazide moiety followed by cyclization as a result of elimination of ammonia molecule. The structure of compound $\mathbf{2 0}$ was confirmed by the IR spectrum which showed a band at $1265(\mathrm{C}=\mathrm{S})$ and the ${ }^{1} \mathrm{H}-\mathrm{NMR}$ spectrum which displayed two peaks at 10.76, 12.22, (2s, 2H, $\mathrm{D}_{2} \mathrm{O}$ exchangeable) corresponding to $\mathrm{NH}$ and $\mathrm{SH}$, respectively.

On the other hand, compound $\mathbf{2 1}$ is formed as a result of nucleaophilic attack of the amino group on one of the carbonyl functionalities of phthalic anhydride accompanied by the cleavage of the five memberd ring then cyclization with the elimination of water molecule to form the 1,3-dioxoisoindoline ring. The structure of $\mathbf{2 1}$ was elucidated depending the IR spectrum which indicated the presence of four absorption bands at 1770, 1742, 1680, 1660 (CO). Also, the mass spectrum showed a molecular ion peak at $\mathrm{m} / \mathrm{z} 468$ (14.2\%).

When Dapson (4,4'-sulfonyldianiline) was reacted with 4-methoxyacetophenone in equimolar amount, the mono imino-compound $\mathbf{2 2}$ was obtained in fair yield. It should be noted that there is a possibility for the formation of diiminated compound, but we isolated only the mono-derivative, where the IR of the product showed bands at 3430 and 3321 $\left(\mathrm{NH}_{2}\right)$. This may be attributed to the use of only one mole of 4-methoxyacetophenone.

Compound 22 was allowed to react with 1-chlorophthalazine derivative 9 in the presence of pyridine, producing the phthalazine derivative $\mathbf{2 3}$ through the nucleophilic attack of the amino group on the carbon atom (bearing chlorine atom) followed by elimination of $\mathrm{HCl}$ molecule. The IR of $\mathbf{2 3}$ showed only on absorption band at 3230 attributable to the NH group.

Reaction of $\mathbf{2 3}$ with 2-furoyl chloride, in dry pyridine, afforded the phthalazine derivative 24 (Chart 6), whose structure was inferred by the IR spectrum which exhibited a strong peak at 1674 attributable to the $\mathrm{C}=\mathrm{O}$ group attached to the furoyl moiety and the mass spectrum which showed a molecular ion peak at $m / z 722(25.7 \%)$.

Compound 24 was formed via tetrahedral mechanism through the attacking of the lone pair of the $\mathrm{NH}$ group of $\mathbf{2 3}$ on the $s p^{2}$ carbon of the carbonyl functionality of furoyl chloride, followed by elimination of $\mathrm{HCl}$ molecule.

Antimicrobial Activity The antimicrobial screening of the synthesized compounds has been evaluated by using agar diffusion method according to Cheesbrough. ${ }^{41)}$ The synthesized compounds have been tested for their antibacterial activity against Bacillus subtilis (ATCC-6633), Staphylococcus aureus (ATCC-25923), Escherichia coli (ATCC-25922) and Pseudomonas aeruginosa (ATCC-9027), and antifungal activity against Candida albicans (ATCC-24433), Aspergillus niger 
<smiles>[Y]Cc1nn(Cc2nnc(S)[nH]2)c(=O)c2ccccc12</smiles>

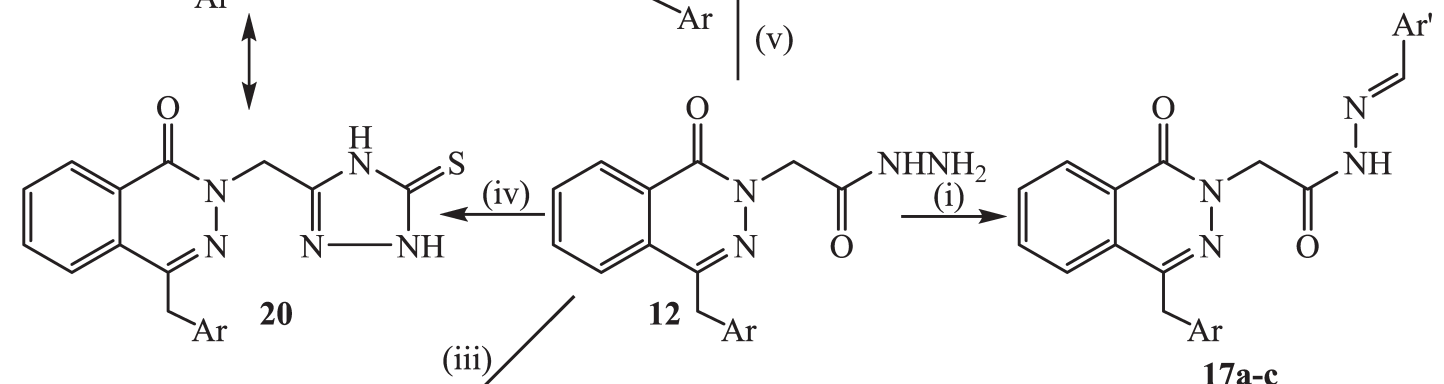

(iii)<smiles>COC(C)=C1C(C)=NN=C1Cn1nc(C[Al])c2ccccc2c1=O</smiles>

$\mathrm{Ar}=4-\mathrm{C}_{6} \mathrm{H}_{4} \mathrm{OMe}$

(ii) a, $\mathrm{Ar}^{\prime}=$ "10

$\mathrm{b}, \mathrm{Ar}^{\prime}=\mathrm{N}^{\mathrm{Y}}$

c, $\mathrm{Ar}^{\prime}=$ 迤 $_{\mathrm{OCH}_{3}}$

Reagents and conditions: (i) $\mathrm{Ar}^{\prime} \mathrm{CHO} / \mathrm{EtOH} / \mathrm{reflux} 3 \mathrm{~h}$ (74-85\%), (ii) $\mathrm{Ac}_{2} \mathrm{O}$ and/or $\mathrm{CH}_{3} \mathrm{COH}_{2} \mathrm{CO}_{2}$ Et/EtOH/reflux 4h (69-77\%), (iii) $\mathrm{CH}{ }_{3} \mathrm{COCH} \mathrm{COCH}_{3} / \mathrm{EtOH}_{2} \mathrm{reflux} 3 \mathrm{~h}$ (71\%), (iv) $\mathrm{NH}_{4} \mathrm{SCN} / \mathrm{EtOH} /$ reflux $3 \mathrm{~h}(61 \%)$, (v) phthalic anhydride/fusion at $170^{\circ} \mathrm{C} /$ for $1 \mathrm{~h}(58 \%)$.

\section{Chart 5}<smiles>Nc1ccc(S(=O)(=O)c2ccc(N)cc2)cc1</smiles>

(i)<smiles>CC(C)=Nc1ccc(S(=O)(=O)c2ccc(N)cc2)cc1</smiles>

(ii)<smiles>O=C(c1ccco1)N(c1ccccc1)c1nnc(C[Al])c2ccccc12</smiles>

Reagents and conditions: (i) 4-Methoxyacetophenone/EtOH/reflux 4h (63\%), (ii) compound 9/ethanol/drops of pyridine/relux $6 \mathrm{~h}$ (58\%), iii) 2-furoyl chloride/dry pyridine/reflux $3 \mathrm{~h}(78 \%)$

Chart 6

(ATCC-16404), at a concentration of $100 \mu \mathrm{g} / \mathrm{mL}$ in dimethyl sulfoxide (DMSO). Nutrient agar and potato dextrose agars were used to culture the bacteria and fungi, respectively. The plates were inculcated by the bacteria or fungi and incubated for $24 \mathrm{~h}$ at $37^{\circ} \mathrm{C}$ for bacteria and for $72 \mathrm{~h}$ at $28^{\circ} \mathrm{C}$ for fungi and then the inhibition zones of microbial growth surrounding the filter paper disc $(5 \mathrm{~mm})$ were measured in millimeters. Ampicillin and Nystatin, at a concentration $100 \mu \mathrm{g} / \mathrm{mL}$, were used as standard against bacteria and fungi, respectively. The obtained results are compiled in Table 1.

From the above table, it is clear that most of the compounds have moderate to strong antimicrobial activity. Compounds 5a, b, 23 and $\mathbf{2 4}$ showed antimicrobial activity higher than the standard compounds, which means that they could be considered as promising antimicrobial agents.

The minimum inhibition concentration for the most potent compounds are recorded in Table 2 using the two fold dilution method. 
Table 1. Antimicrobial Screening Results of the Tested Compounds (Inhibition Zones)

\begin{tabular}{|c|c|c|c|c|c|c|}
\hline \multirow{3}{*}{ Cmpd No. } & \multicolumn{4}{|c|}{ Antibacterial activity (mm) } & \multicolumn{2}{|c|}{ Antifungal activity (mm) } \\
\hline & \multicolumn{2}{|c|}{ Gram-positive bacteria } & \multicolumn{2}{|c|}{ Gram-negative bacteria } & \multirow{2}{*}{ Candida albicans } & \multirow{2}{*}{ Aspergillus niger } \\
\hline & Bacillus subtilis & Staphylococcus aureus & Escherichia coli & Pseudomonas aeruginosa & & \\
\hline 3 & 17 & 14 & 13 & 14 & 16 & 13 \\
\hline $4 a$ & 14 & 13 & 11 & 10 & 12 & 10 \\
\hline $4 b$ & 13 & 10 & 12 & 12 & 14 & 11 \\
\hline $5 a$ & 27 & 26 & 22 & 22 & 24 & 20 \\
\hline $5 \mathbf{b}$ & 28 & 26 & 21 & 20 & 23 & 18 \\
\hline $6 \mathbf{a}$ & 20 & 17 & 14 & 15 & 17 & 13 \\
\hline $6 b$ & 17 & 16 & 13 & 14 & 14 & 11 \\
\hline $7 a$ & 16 & 18 & 17 & 17 & 14 & 12 \\
\hline $7 b$ & 18 & 17 & 16 & 18 & 19 & 15 \\
\hline $8 a$ & 22 & 19 & 18 & 16 & 16 & 11 \\
\hline $8 b$ & 19 & 18 & 15 & 13 & 14 & 12 \\
\hline 9 & 14 & 12 & 10 & 10 & 15 & 13 \\
\hline 10 & 17 & 15 & 12 & 11 & 15 & 10 \\
\hline 11 & 11 & 14 & 10 & 12 & 11 & 12 \\
\hline 12 & 23 & 21 & 18 & 18 & 20 & 17 \\
\hline 13 & 19 & 16 & 16 & 13 & 18 & 15 \\
\hline 14 & 15 & 14 & 12 & 12 & 10 & 11 \\
\hline 15 & 19 & 17 & 14 & 15 & 11 & 11 \\
\hline 16 & 16 & 18 & 17 & 19 & 15 & 14 \\
\hline $17 \mathbf{a}$ & 23 & 20 & 18 & 15 & 17 & 13 \\
\hline $17 b$ & 22 & 20 & 19 & 18 & 18 & 15 \\
\hline $17 \mathrm{c}$ & 18 & 19 & 16 & 13 & 10 & 11 \\
\hline $18 \mathrm{a}$ & 17 & 18 & 18 & 15 & 16 & 14 \\
\hline $18 \mathrm{~b}$ & 18 & 16 & 14 & 17 & 15 & 11 \\
\hline 19 & 21 & 18 & 15 & 14 & 12 & 16 \\
\hline 20 & 22 & 20 & 17 & 18 & 19 & 15 \\
\hline 21 & 16 & 19 & 17 & 17 & 15 & 12 \\
\hline 23 & 28 & 25 & 22 & 21 & 23 & 21 \\
\hline 24 & 26 & 24 & 22 & 20 & 24 & 19 \\
\hline Ampicillin & 25 & 22 & 20 & 19 & - & - \\
\hline Nystatin & - & - & - & - & 22 & 18 \\
\hline
\end{tabular}

Cmpd No: compound number; mm: millimeter.

Table 2. MICs for the Most Potent Compounds $(\mu \mathrm{g} / \mathrm{mL})$

\begin{tabular}{|c|c|c|c|c|c|c|}
\hline \multirow{2}{*}{ Cmpd No. } & \multicolumn{2}{|c|}{ Gram-positive bacteria } & \multicolumn{2}{|c|}{ Gram-negative bacteria } & \multicolumn{2}{|c|}{ Fungi } \\
\hline & Bacillus subtilis & Staphylococcus aureus & Escherichia coli & Pseudomonas aeruginosa & Candida albicans & Aspergillus niger \\
\hline $5 \mathbf{a}$ & 12.5 & 12.5 & 50 & 50 & 25 & 50 \\
\hline $5 \mathbf{b}$ & 12.5 & 12.5 & 50 & 50 & 25 & 50 \\
\hline 23 & 12.5 & 25 & 50 & 50 & 25 & 50 \\
\hline 24 & 12.5 & 25 & 50 & 50 & 25 & 50 \\
\hline
\end{tabular}

The inhibitory capability of the most active compounds (5a, b, 23 and 24) was demonstrated in Figs. 1A and B. These potent compounds showed higher activity against Grampositive bacteria (Bacillus subtilis and Staphylococcus aureus) compared with Gram-negative bacteria (Escherichia coli and Pseudomonas aeruginosa). On the other hand less activity was showed against both fungal strains Candida albicans and Aspergillus niger.

\section{Experimental}

All melting points are uncorrected and were determined on a Gallen Kamp electric melting point apparatus. The microanalyses were within $\pm 0.4 \%$ of theoretical values and were carried out at the Microanalytical Centre, National Research Centre, Cairo, Egypt. IR spectra (in $\mathrm{KBr}$ ) were recorded on Shimadzu FT-IR 8101 PC using the OMNIC program and are reported as frequency of absorption in $\mathrm{cm}^{-1}$. ${ }^{1} \mathrm{H}-\mathrm{NMR}$ spectra were recorded on a Bruker spectrophotometer at $400 \mathrm{MHz}$ using tetramethylsilane (TMS) as internal standard. ${ }^{13} \mathrm{C}-\mathrm{NMR}$ spectra were recorded on the same spectrometer at $100 \mathrm{MHz}$. Electron Ionization (EI)-MS were measured on a ShimadzuGC-MS-QP-1000 EX mass spectrometer instrument operating at $70 \mathrm{eV}$. The purity of the new synthesized compounds was checked by $0.2 \mathrm{~mm}$ layer thickness Fluka aluminum-backed TLC plates with detection by UV quenching at $254 \mathrm{~nm}$. Biological evaluation was carried out at Microbiology Depart- 


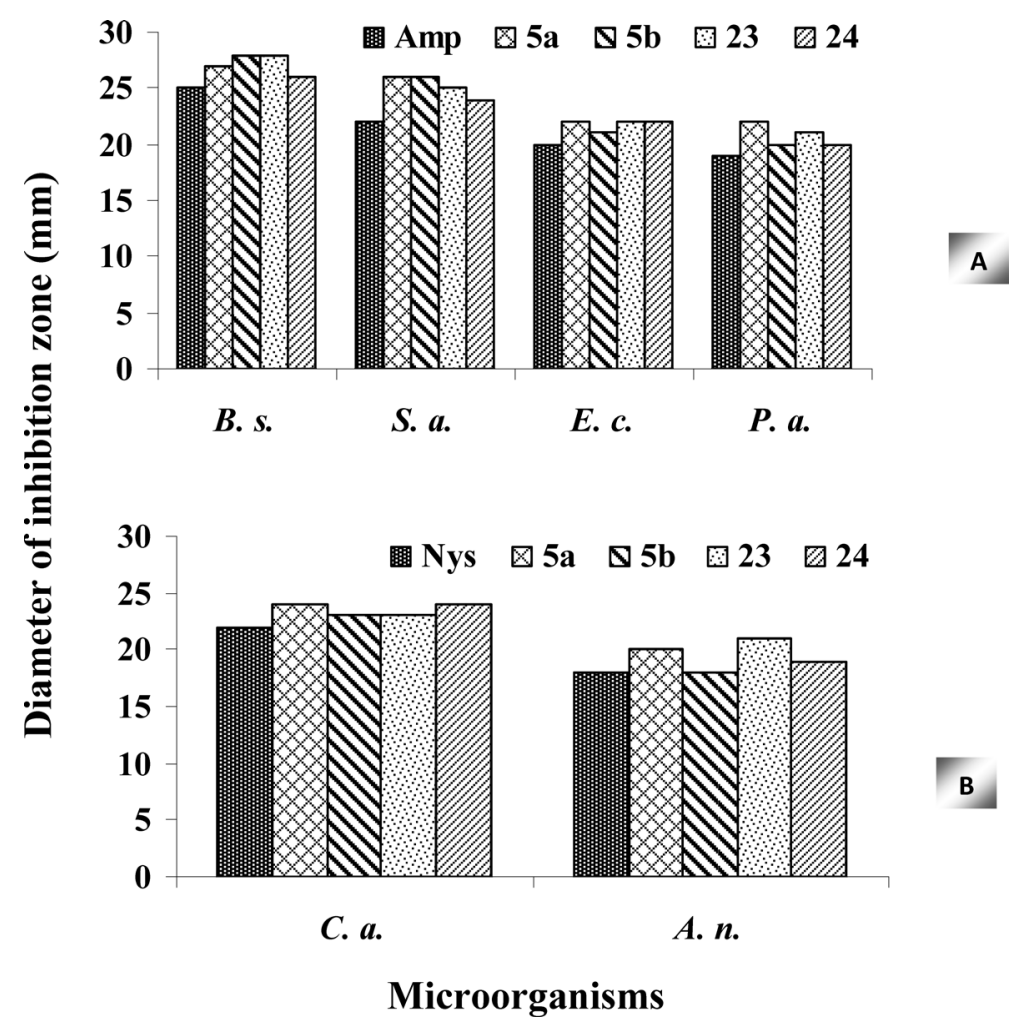

Fig. 1. Antimicrobial Activity of the Most Potent Compounds against Different Bacterial (A) and Fungal (B) Strains

B. s.: Bacillus subtilis; S. a.: Staphylococcus aureus; E. c.: Escherichia coli; P. s.: Pseudomonas aeruginosa; C. a.: Candida albicans and A. n.: Aspergillus niger. Nys: nystatin; Amp: ampicillin.

ment, Ain Shams University, Faculty of Science, Ain Shams University, Cairo, Egypt. Reagents and solvents were used as obtained from the supplier without further purification.

4-(4-Methoxybenzyl)phthalazin-1(2H)-one

(3) This compound was previously prepared by Olmo et al., ${ }^{33)}$ but no spectroscopic data or chemical analysis was recorded in their paper for this compound. Herein, this compound was prepared according to different previously reported methodology. ${ }^{34)}$

Yield 93\%. mp 254-256 ${ }^{\circ} \mathrm{C}$. IR (KBr), $v \mathrm{~cm}^{-1}$ : 3199 (NH), 1661(CO), $1610(\mathrm{C}=\mathrm{N}) .{ }^{1} \mathrm{H}-\mathrm{NMR}\left(400 \mathrm{MHz}, \mathrm{DMSO}-d_{6}\right) \delta: 3.69$ (s, $\left.3 \mathrm{H}, \mathrm{OCH}_{3}\right), 4.22\left(\mathrm{~s}, 2 \mathrm{H}, \mathrm{CH}_{2} \mathrm{Ar}\right), 7.33-8.34(\mathrm{~m}, 4 \mathrm{H}, \mathrm{ArH})$, $12.74\left(\mathrm{~s}, 1 \mathrm{H}, \mathrm{NH}, \mathrm{D}_{2} \mathrm{O}\right.$ exchangeable). ${ }^{13} \mathrm{C}-\mathrm{NMR}(100 \mathrm{MHz}$, DMSO- $\left.d_{6}\right) \delta$ ppm: $35.13,55.79,113.39,122.51,126.15,127.36$, 128.56, 130.23, 132.19, 133.62, 153.44, 154.33, 156.09, 163.14 . MS: $m / z 266\left[\mathrm{M}^{+}\right]$(100\%). Anal. Calcd for $\mathrm{C}_{16} \mathrm{H}_{14} \mathrm{~N}_{2} \mathrm{O}_{2}(266)$ : C, 72.18; H, 5.26; N, 10.52. Found: C, 72.49; H, 5.09; N, 10.90 .

General Procedure for the Synthesis of the Phthalazinones $4 a$ and $b$ A mixture of 4-(4-methoxybenzyl)- $1 \mathrm{H}$ benzo[ $d][1,2]$ oxazin-1-one (2) $(2.67 \mathrm{~g}, 0.01 \mathrm{~mol})$ and 1,4-phenylene diamine, and/or 4,4'-benzidine $(0.01 \mathrm{~mol})$ was heated under reflux in absolute ethanol $(20 \mathrm{~mL})$ for $6 \mathrm{~h}$. The resulting mixture was cooled and then poured onto an ice/water mixture. The separated solid was filtered, washed with water, airdried and crystallized from ethanol.

2-(4-Aminophenyl)-4-(4-methoxybenzyl)phthalazin-1(2H)one (4a)

Yield 76\%. mp 168-170 ${ }^{\circ} \mathrm{C}$. IR (KBr), $v\left(\mathrm{~cm}^{-1}\right): 3348,3287$ $\left(\mathrm{NH}_{2}\right), 1665(\mathrm{C}=\mathrm{O}), 1619(\mathrm{C}=\mathrm{N}) .{ }^{1} \mathrm{H}-\mathrm{NMR}(400 \mathrm{MHz}$, DMSO$\left.d_{6}\right) \delta: 3.70\left(\mathrm{~s}, 3 \mathrm{H}, \mathrm{OCH}_{3}\right), 4.23\left(\mathrm{~s}, 2 \mathrm{H}, \mathrm{CH}_{2} \mathrm{Bz}\right), 6.39(\mathrm{~s}, 2 \mathrm{H}$, $\mathrm{NH}_{2}, \mathrm{D}_{2} \mathrm{O}$ exchangeable), 7.18-8.26 (m, $\left.12 \mathrm{H}, \mathrm{ArH}\right) .{ }^{13} \mathrm{C}-\mathrm{NMR}$ $\left(100 \mathrm{MHz}, \mathrm{DMSO}-d_{6}\right) \delta$ ppm: 35.01, 56.22, 114.51, 120.81,
122.51, 126.68, 127.31, 128.72, 129.62, 130.18, 131.18, 133.41, 146.92, 147.58, 154.01, 156.02, 158.12, 162.90. MS: $\mathrm{m} / \mathrm{z} 357$ [M+'] (27.9). Anal. Calcd for $\mathrm{C}_{22} \mathrm{H}_{19} \mathrm{~N}_{3} \mathrm{O}_{2}$ (357): C, 73.95; H, 5.32; N, 11.76. Found: C, 74.31; H, 5.54; N, 12.05 .

2-(4'-Amino-[1,1'-biphenyl]-4-yl)-4-(4-methoxybenzyl)phthalazin- $1(2 H)$-one $(\mathbf{4 b})$

Yield $68 \%$. mp $182-184^{\circ} \mathrm{C}$. IR $(\mathrm{KBr}), v\left(\mathrm{~cm}^{-1}\right)$ : 3339, $3283\left(\mathrm{NH}_{2}\right), 1669(\mathrm{C}=\mathrm{O}), 1622(\mathrm{C}=\mathrm{N}) .{ }^{1} \mathrm{H}-\mathrm{NMR}(400 \mathrm{MHz}$, DMSO- $\left.d_{6}\right) \delta: 3.74\left(\mathrm{~s}, 3 \mathrm{H}, \mathrm{OCH}_{3}\right), 4.25\left(\mathrm{~s}, 2 \mathrm{H}, \mathrm{CH}_{2} \mathrm{Bz}\right), 6.23$ (s, $\left.2 \mathrm{H}, \mathrm{NH}_{2}\right), 7.08-8.19(\mathrm{~m}, 16 \mathrm{H}, \mathrm{ArH}) .{ }^{13} \mathrm{C}-\mathrm{NMR}(100 \mathrm{MHz}$, DMSO- $\left.d_{6}\right) \delta$ ppm: $35.42,54.91,114.41,120.82,122.01,122.99$, $125.11,126.72,127.32,128.69,130.21,131.01,132.12,133.39$, $134.78,137.21,140.11,146.89,150.01,154.09,156.58,162.81$. MS: $m / z 433\left[\mathrm{M}^{+}\right]$(35.7). Anal. Calcd for $\mathrm{C}_{28} \mathrm{H}_{23} \mathrm{~N}_{3} \mathrm{O}_{2}$ (433): C, 77.60; H, 5.31; N, 9.70. Found: C, 77.44; H, 5.04; N, 10.02 .

General Procedure for the Synthesis of the Schiff Bases 5a and $\mathbf{b}$ A mixture of compounds $4 \mathbf{a}$ and $\mathbf{b}(0.01 \mathrm{~mol})$ and 4-methoxybenzaldehyde $(1.36 \mathrm{~g}, 0.01 \mathrm{~mol})$ was heated under reflux in absolute ethanol $(20 \mathrm{~mL})$ for $3 \mathrm{~h}$. The resulting mixture was cooled and then poured onto an ice/water mixture. The separated solid was filtered, washed with water, dried and then crystallized from ethanol.

4-(4-Methoxybenzyl)-2-(4-((4-methoxybenzylidene)amino)phenyl)phthalazin-1(2H)-one (5a)

Yield $80 \%$. mp $200-202^{\circ} \mathrm{C}$ : IR $(\mathrm{KBr}), v\left(\mathrm{~cm}^{-1}\right)$ : 1668 $(\mathrm{C}=\mathrm{O}), 1615 \quad(\mathrm{C}=\mathrm{N}) .{ }^{1} \mathrm{H}-\mathrm{NMR} \quad\left(400 \mathrm{MHz}\right.$, DMSO- $\left.d_{6}\right) \delta$ : 3.65, $3.78\left(2 \mathrm{~s}, 6 \mathrm{H}, 2 \mathrm{OCH}_{3}\right), 4.22\left(\mathrm{~s}, 2 \mathrm{H}, \mathrm{CH}_{2} \mathrm{Bz}\right), 6.68$ (s, $1 \mathrm{H},=\mathrm{CH}-), 7.18-8.19(\mathrm{~m}, 16 \mathrm{H}, \mathrm{ArH}) .{ }^{13} \mathrm{C}-\mathrm{NMR}(100 \mathrm{MHz}$, DMSO- $\left.d_{6}\right) \delta$ ppm: $35.23,54.89,55.12,116.49,120.81,122.51$, $126.59,127.31,129.22,130.44,132.04,133.19,134.39,136.55$, $140.81,142.51,146.59,148.68,149.31,151.72,153.59,155.62$, 
158.18, 164.92. MS: $m / z 475\left[\mathrm{M}^{+}\right]$(40\%). Anal. Calcd for $\mathrm{C}_{30} \mathrm{H}_{25} \mathrm{~N}_{3} \mathrm{O}_{3}$ (475): C, 75.79; H, 5.26; N, 8.84. Found: C, 76.16; $\mathrm{H}, 5.00 ; \mathrm{N}, 8.55$.

4-(4-Methoxybenzyl)-2-(4'-((3-methoxybenzylidene)amino)[1,1'-biphenyl]-4-yl)phthalazin-1(2H)-one (5b)

Yield 74\%. mp 212-214 ${ }^{\circ} \mathrm{C}$. IR (KBr), $v\left(\mathrm{~cm}^{-1}\right)$ : $1667(\mathrm{C}=\mathrm{O})$, $1617(\mathrm{C}=\mathrm{N}) .{ }^{1} \mathrm{H}-\mathrm{NMR}\left(400 \mathrm{MHz}, \mathrm{DMSO}-d_{6}\right) \quad \delta: 3.62,3.79$ $\left(2 \mathrm{~s}, 6 \mathrm{H}, 2 \mathrm{OCH}_{3}\right), 4.19\left(\mathrm{~s}, 2 \mathrm{H}, \mathrm{CH}_{2} \mathrm{Bz}\right), 6.75(\mathrm{~s}, 1 \mathrm{H},=\mathrm{CH}-)$; 7.24-8.22 (m, 20H, ArH). ${ }^{13} \mathrm{C}-\mathrm{NMR}\left(100 \mathrm{MHz}, \mathrm{DMSO}-d_{6}\right) \delta$ ppm: $35.77,54.96,55.80,116.41,119.19,120.62,122.69,123.87$, $125.11,126.19,126.72,127.32,128.69,130.21,131.01,132.12$, $133.39,134.42,135.78,136.44,137.21,138.88,140.11,146.89$, 150.01, 154.00, 158.54, 165.58. MS: $m / z 551\left[\mathrm{M}^{+}\right](35.7 \%)$. Anal. Calcd for $\mathrm{C}_{36} \mathrm{H}_{29} \mathrm{~N}_{3} \mathrm{O}_{3}$ (551): C, 78.40; H, 5.26; N, 7.62. Found: C, 78.07; H, 5.00; N, 7.29.

Synthesis of 1,3-Diazetidine Derivatives 7a and b Equimolar amounts of 5a and $\mathbf{b}(0.01 \mathrm{~mol})$ and phenyl isothiocyanate $(1.35 \mathrm{~g}, 0.01 \mathrm{~mol})$ in $25 \mathrm{~mL}$ toluene was refluxed for $6 \mathrm{~h}$. The solvent was distilled off and the residue was washed with ethanol followed by water, and the product was crystallized from ethanol.

4 -(4-Methoxybenzyl)-2-(4-(2-(4-methoxy phenyl)-3phenyl-4-thioxo-1,3-diazetidin-1-yl)phenyl)-phthalazin-1(2H)one (7a)

Yield 68\%. mp $278-280^{\circ} \mathrm{C}$. IR (KBr), $v\left(\mathrm{~cm}^{-1}\right)$ : $1664(\mathrm{C}=\mathrm{O})$, $1614(\mathrm{C}=\mathrm{N}), 1319(\mathrm{C}=\mathrm{S}) .{ }^{1} \mathrm{H}-\mathrm{NMR}\left(400 \mathrm{MHz}, \mathrm{DMSO}-d_{6}\right) \delta$ : 3.61, $3.76\left(2 \mathrm{~s}, 6 \mathrm{H}, 2 \mathrm{OCH}_{3}\right), 4.21\left(\mathrm{~s}, 2 \mathrm{H} ; \mathrm{CH}_{2} \mathrm{Bz}\right), 6.56(\mathrm{~s}, 1 \mathrm{H}$, benzylic H), 7.15-8.20 (m, 21H, ArH). ${ }^{13} \mathrm{C}-\mathrm{NMR}(100 \mathrm{MHz}$, DMSO- $\left.d_{6}\right) \delta$ ppm: 35.33, 55.44, 56.05, 95.46, 115.91, 116.19, $120.62,122.69,126.67,128.23,128.89,129.73,130.32,130.91$, $131.91,132.21,133.66,134.40,135.66,136.41,137.03,137.79$, $141.14,144.87,153.23,154.55,158.89,166.67,174.21 . \mathrm{MS}: \mathrm{m} / \mathrm{z}$ $610\left[\mathrm{M}^{+}\right]$(59.1\%): Anal. Calcd for $\mathrm{C}_{37} \mathrm{H}_{30} \mathrm{~N}_{4} \mathrm{O}_{3} \mathrm{~S}$ (610): C, 72.79; H, 4.92; N, 9.18; S, 5.25. Found: C, 73.15; H, 5.21; N, 9.55; S, 5.63 .

4-(4-Methoxybenzyl)-2-(4'-(2-(4-methoxy phenyl)-3phenyl-4-thioxo-1,3-diazetidin-1-yl)-[1,1'-biphenyl]-4-yl)phthalazin-1(2H)-one (7b)

Yield $72 \%$. mp $284-286^{\circ} \mathrm{C}$. IR ( $\left.\mathrm{KBr}\right), v\left(\mathrm{~cm}^{-1}\right)$ : $1671(\mathrm{C}=\mathrm{O})$, $1522(\mathrm{C}=\mathrm{N}), 1322(\mathrm{C}=\mathrm{S}) .{ }^{1} \mathrm{H}-\mathrm{NMR}\left(400 \mathrm{MHz}, \mathrm{DMSO}-d_{6}\right) \delta$ : 3.64, $3.73\left(2 \mathrm{~s}, 6 \mathrm{H}, 2 \mathrm{OCH}_{3}\right), 4.24$ (s, 2H; $\left.\mathrm{CH}_{2} \mathrm{Bz}\right), 6.61(\mathrm{~s}, 1 \mathrm{H}$, benzylic H), 7.13-8.25 (m, 25H, ArH). ${ }^{13} \mathrm{C}-\mathrm{NMR}(100 \mathrm{MHz}$, DMSO- $\left.d_{6}\right) \delta$ ppm: $35.45,55.23,55.89,96.12,115.78,117.02$, $121.82,122.56,126.88,127.49,128.12,128.78,129.33,129.81$, $130.24,130.98,131.66,132.29,133.69,134.51,135.72,136.32$, $137.22,138.12,138.82,139.39,140.51,141.32,142.67,152.88$, 154.34, 159.61, 165.58, 174.99. MS: $m / z 686\left[\mathrm{M}^{+}\right](66.3 \%)$. Anal. Calcd for $\mathrm{C}_{43} \mathrm{H}_{34} \mathrm{~N}_{4} \mathrm{O}_{3} \mathrm{~S}$ (686): C, 75.22; H, 4.96; N, 8.16; S, 4.67. Found: C, 74.90; H, 5.23; N, 7.88; S, 5.00.

Synthesis of Acetylated Derivatives $6 a$ and $b$ and Deacetylated Derivatives 8a and b A mixture of phthalazinones $\mathbf{2 a}$ and $\mathbf{b}(0.01 \mathrm{~mol})$ and 2-bromo-2-deoxy-1,3,4,6tetra- $O$-acetyl- $\alpha$-D-glucopyranose $(4.1 \mathrm{~g}, 0.01 \mathrm{~mol})$ in $100 \mathrm{~mL}$ 1,4-dioxane was heated with frequent stirring under reflux for $4 \mathrm{~h}$. The mixture was cooled to room temperature and the solvent was removed under reduced pressure. The residue was dissolved in ethyl acetate, washed sequentially with saturated $\mathrm{NaHCO}_{3}(3 \times 20 \mathrm{~mL})$, then with water and dried over $\mathrm{MgSO}_{4}$. The purification and separation was achieved by column chromatography (EtOAc-hexane, 3:1) giving the acetylated products $\mathbf{6 a}$ and $\mathbf{b}$ as a white solid which was later on recrys- tallized using diethyl ether-hexane as a solvent. A solution of 6a and $\mathbf{b}$ in $\mathrm{MeOH}(50 \mathrm{~mL})$ was treated with sodium carbonate solution $(2.12 \mathrm{~g}, 0.05 \mathrm{~mol}$ in $20 \mathrm{~mL}$ water). After stirring for $30 \mathrm{~min}$, a white solid syrupy began to settle. The residue was then purified by column chromatography (EtOAc-hexane, $3: 1)$ giving the deacetylated derivatives each as a white solid, which was crystallized by dichloromethane-diethyl ether as a solvent, affording $\mathbf{8 a}$ and $\mathbf{b}$, respectively.

6 -(Acetoxy methyl)-3-((4-(4-(4-methoxybenzyl) - oxophthalazin-2(1H)-yl)phenyl)amino)-tetrahydro-2 $H$ pyran-2,4,5-triyl Triacetate (6a)

Yield 58\%. mp $124-126^{\circ} \mathrm{C}$. IR (KBr), $v\left(\mathrm{~cm}^{-1}\right)$ : $3334(\mathrm{NH})$; 1685, 1671, $1660(\mathrm{C}=\mathrm{O}),{ }^{1} \mathrm{H}-\mathrm{NMR}\left(400 \mathrm{MHz}, \mathrm{DMSO}-d_{6}\right) \delta$ : 2.08-2.29 (s, 12H, $\left.4 \mathrm{COCH}_{3}\right), 3.65\left(\mathrm{~s}, 3 \mathrm{H}, \mathrm{OCH}_{3}\right), 4.18(\mathrm{~s}, 2 \mathrm{H}$, $\left.\mathrm{CH}_{2} \mathrm{Bz}\right), 4.32-5.87$ (m, 7H, $\mathrm{CH}_{2} \mathrm{OAc}$ and pyran-H), 7.18-8.28 $(\mathrm{m}, 12 \mathrm{H}, \mathrm{ArH}), 11.03\left(\mathrm{~s}, 1 \mathrm{H}, \mathrm{NH}, \mathrm{D}_{2} \mathrm{O}\right.$ exchangeable). ${ }^{13} \mathrm{C}-\mathrm{NMR}\left(100 \mathrm{MHz}, \mathrm{DMSO}-d_{6}\right) \delta \mathrm{ppm}: 22.02,22.81,36.11$, 55.37, 61.39, 70.89, 71.91, 72.38, 73.10, 92.89, 115.44, 118.89, $121.11,122.42,126.59,127.32,128.42,130.38,131.11,132.42$, 136.59, 136.71, 143.19, 146.90, 154.01, 160.58, 171.20, 174.21, MS: $m / z\left[\mathrm{M}^{+}\right] 687$ (1.4\%). Anal. Calcd for $\mathrm{C}_{36} \mathrm{H}_{37} \mathrm{~N}_{3} \mathrm{O}_{11}$ (687): C, 62.88; H, 5.39; N, 6.11. Found: C, 63.24; H, 5.08; N, 5.78.

6 -(Acetoxymethyl)-3-((4'-(4-(4-methoxybenzyl)-1oxophthalazin-2(1H)-yl)-[1,1'-biphenyl]-4-yl)amino)tetrahydro-2H-pyran-2,4,5-triyl Triacetate $(\mathbf{6 b})$

Yield 56\%. mp $164-166^{\circ} \mathrm{C}$. IR (KBr), $v\left(\mathrm{~cm}^{-1}\right)$ : $3311(\mathrm{NH})$; 1683, 1673, $1662(\mathrm{C}=\mathrm{O}),{ }^{1} \mathrm{H}-\mathrm{NMR}\left(400 \mathrm{MHz}, \mathrm{DMSO}-d_{6}\right) \delta$ : 2.05-2.24 (s, 12H, $\left.4 \mathrm{COCH}_{3}\right), 3.68\left(\mathrm{~s}, 3 \mathrm{H}, \mathrm{OCH}_{3}\right), 4.24(\mathrm{~s}, 2 \mathrm{H}$, $\left.\mathrm{CH}_{2} \mathrm{Bz}\right), 4.34-5.84\left(\mathrm{~m}, 7 \mathrm{H}, \mathrm{CH}_{2} \mathrm{OAc}\right.$ and pyran-H), 7.22-8.24 $(\mathrm{m}, 16 \mathrm{H}, \mathrm{ArH}), 10.89$ (s, 1H, NH, $\mathrm{D}_{2} \mathrm{O}$ exchangeable). ${ }^{13} \mathrm{C}-\mathrm{NMR}\left(100 \mathrm{MHz}, \mathrm{DMSO}-d_{6}\right) \delta \mathrm{ppm}: 21.82,23.01,35.89$, 55.90, 61.01, 70.22, 71.39, 72.54, 74.45, 88.21, 114.89, 115.55, $120.78,122.01,125.11,126.59,127.72,128.29,130.22,131.43$, $132.62,133.41,134.38,137.20,140.78,142.01,145.11,146.72$, 154.00, 160.59, 172.20, 173.92. MS: $m / z 763\left[\mathrm{M}^{+}\right](10.9 \%)$. Anal. Calcd for $\mathrm{C}_{42} \mathrm{H}_{41} \mathrm{~N}_{3} \mathrm{O}_{11}$ (763): C, 66.06; H, 5.37; N, 5.50. Found: C, 66.43; H, 5.70; N, 5.16.

4 - (4 - Methoxybenzyl) - $-(4-((2,4,5$ - trihydroxy- 6 (hydroxymethyl)tetrahydro-2 $H$-pyran-3-yl)amino)-phenyl)phthalazin-1 $(2 H)$-one $(\mathbf{8 a})$

Yield $48 \%$. mp $158-160^{\circ} \mathrm{C}$. IR (KBr), $v\left(\mathrm{~cm}^{-1}\right)$ : 3384,3278 $(\mathrm{OH}$ bonded and non-bonded), $3185(\mathrm{NH}), 1664(\mathrm{C}=\mathrm{O})$. ${ }^{1} \mathrm{H}-\mathrm{NMR}\left(400 \mathrm{MHz}, \mathrm{DMSO}-d_{6}\right) \delta: 3.20-3.61$ (m, 6H, glucose$\mathrm{H}), 3.78\left(\mathrm{~s}, 3 \mathrm{H}, \mathrm{OCH}_{3}\right), 4.15\left(\mathrm{~s}, 2 \mathrm{H}, \mathrm{CH}_{2} \mathrm{Bz}\right), 4.28,4.44,4.59$, $4.74\left(\mathrm{~s}, 4 \mathrm{H}, 4 \mathrm{OH}\right.$ of glucose, $\mathrm{D}_{2} \mathrm{O}$ exchangeable), $5.21(\mathrm{~d}, 1 \mathrm{H}$, $\left.\mathrm{H}_{\text {anom }}, J=7.9 \mathrm{~Hz}\right), 7.13-8.31(\mathrm{~m}, 12 \mathrm{H}, \mathrm{Ar}-\mathrm{H}), 9.37(\mathrm{~s}, 1 \mathrm{H}, \mathrm{NH}$, $\mathrm{D}_{2} \mathrm{O}$ exchangeable). ${ }^{13} \mathrm{C}-\mathrm{NMR}\left(100 \mathrm{MHz}, \mathrm{DMSO}-d_{6}\right) \delta \mathrm{ppm}$ : $35.01,55.99,61.87,63.89,70.21,73.38,74.11,94.62,115.34$, $116.88,121.11,124.44,128.61,129.70,130.89,131.52,131.78$, $132.05,132.57,135.39,144.18,153.90,156.03,160.59$. MS: $m / z$ $519\left[\mathrm{M}^{+}\right]$(25.2\%). Anal. Calcd for $\mathrm{C}_{28} \mathrm{H}_{29} \mathrm{~N}_{3} \mathrm{O}_{7}$ (519): C, 64.74; H, 5.59; N, 8.09. Found: C, 65.09; H, 5.81; N, 8.43.

4 - (4 - Methoxybenzyl) - $-\left(4^{\prime}-((2,4,5\right.$ - trihydroxy- 6 (hydroxymethyl)tetrahydro-2 $H$-pyran-3-yl)amino)-[1, $1^{\prime}$ biphenyl]-4-yl)phthalazin-1(2H)-one (8b)

Yield $43 \%$. mp $188-190^{\circ} \mathrm{C}$. IR (KBr), $v\left(\mathrm{~cm}^{-1}\right)$ : 3379, 3261, $(\mathrm{OH}$ bonded and non-bonded), $3191(\mathrm{NH}), 1669(\mathrm{C}=\mathrm{O})$. ${ }^{1} \mathrm{H}-\mathrm{NMR}\left(400 \mathrm{MHz}, \mathrm{DMSO}-d_{6}\right) \delta: 3.23-3.66(\mathrm{~m}, 6 \mathrm{H}$, glucose$\mathrm{H}), 3.82\left(\mathrm{~s}, 3 \mathrm{H}, \mathrm{OCH}_{3}\right), 4.10\left(\mathrm{~s}, 2 \mathrm{H}, \mathrm{CH}_{2} \mathrm{Bz}\right), 4.33,4.51,4.66$, 4.79 (s, 4H, 4OH of glucose, $\mathrm{D}_{2} \mathrm{O}$ exchangeable), $5.32(\mathrm{~d}, 1 \mathrm{H}$, $\left.\mathrm{H}_{\text {anom }}, J=8.3 \mathrm{~Hz}\right), 7.09-8.41(\mathrm{~m}, 16 \mathrm{H}, \mathrm{Ar}-\mathrm{H}), 9.88(\mathrm{~s}, 1 \mathrm{H}, \mathrm{NH}$, 
$\mathrm{D}_{2} \mathrm{O}$ exchangeable). ${ }^{13} \mathrm{C}-\mathrm{NMR}\left(100 \mathrm{MHz}, \mathrm{DMSO}-d_{6}\right) \delta \mathrm{ppm}$ : 35.47, 56.23, 60.99, 64.12, 71.87, 74.81, 75.43, 95.59, 114.91, $116.64,121.52,122.79,124.78,126.23,127.83,128.57,129.54$, $130.58,131.33,131.97,132.21,132.88,134.41,137.39,138.68$, 154.48, 156.87, 161.24. MS: $m / z 595\left[\mathrm{M}^{+}\right]$(34.2\%). Anal. Calcd for $\mathrm{C}_{34} \mathrm{H}_{33} \mathrm{~N}_{3} \mathrm{O}_{7}$ (595): C, 68.57; H, 5.55; N, 7.06. Found: C, 68.89; H, 5.84; N, 6.73.

Synthesis of 1-Chloro-4-(4-methoxybenzyl)phthalazine (9) Compound $3(2.66 \mathrm{~g}, 0.01 \mathrm{~mol})$ was added to a mixture of $5 \mathrm{~mL} \mathrm{POCl}_{3}$ and $2 \mathrm{~g} \mathrm{PCl}_{5}$. The reaction mixture was refluxed for $4 \mathrm{~h}$, then poured drop wise of ice/water mixture with vigorous stirring. The precipitate so formed was filtered of, washed with water several times, dried then recrystallized from ethanol.

Yield $84 \%$. mp $155-157^{\circ} \mathrm{C}$. IR (KBr), $v\left(\mathrm{~cm}^{-1}\right)$ : 3059-2993 $(\mathrm{CH}), 1610(\mathrm{C}=\mathrm{N}) .{ }^{1} \mathrm{H}-\mathrm{NMR}\left(400 \mathrm{MHz}, \mathrm{DMSO}-d_{6}\right) \delta: 3.66$ (s, 3H, $\left.\mathrm{OCH}_{3}\right), 4.27$ (s, 2H, $\left.\mathrm{CH}_{2} \mathrm{Bz}\right), 7.12-8.09$ (m, 8H, ArH). ${ }^{13} \mathrm{C}-\mathrm{NMR}\left(100 \mathrm{MHz}, \mathrm{DMSO}-d_{6}\right) \delta$ ppm: $35.59,56.33,115.53$, $124.19,125.34,126.86,127.76,128.89,130.11,132.34,133.73$, 154.32, 156.31, 159.03. MS: $m / z 284[\mathrm{M}]^{+}(28.9 \%), 286[\mathrm{M}+2]$ (10.1\%). Anal. Calcd for $\mathrm{C}_{16} \mathrm{H}_{13} \mathrm{~N}_{2} \mathrm{OCl}$ (284): C, 67.61; H, 4.58; $\mathrm{N}, 9.86 ; \mathrm{Cl}, 12.50$. Found: C, 67.93; H, 4.31; N, 10.23, Cl, 12.12 .

Synthesis of Ethyl-2-(4-(4-methoxybenzyl)-1-oxophthalazin-2-yl)acetate (10) A mixture of phthalazinone derivative $3(2.66 \mathrm{~g}, 0.01 \mathrm{~mol})$, ethylchloroacetate $(2.44 \mathrm{~g}$, $0.02 \mathrm{~mol})$ and anhydrous potassium carbonate $(5.52 \mathrm{~g}$, $0.04 \mathrm{~mol})$ in dry acetone $(50 \mathrm{~mL})$ was refluxed for $24 \mathrm{~h}$. The excess solvent was then removed by distillation and the residue was diluted with water. The obtained solid was filtered off and crystallized from benzene.

Yield $80 \%$. mp $102-104^{\circ} \mathrm{C}$. IR $(\mathrm{KBr}), v\left(\mathrm{~cm}^{-1}\right)$ : 3042-2885 $(\mathrm{CH}), 1745,1684$ (CO), $1614(\mathrm{C}=\mathrm{N}) .{ }^{1} \mathrm{H}-\mathrm{NMR} \quad(400 \mathrm{MHz}$, DMSO- $\left.d_{6}\right) \delta$ : $1.34\left(\mathrm{t}, 3 \mathrm{H}, \mathrm{CH}_{3}, J=6.1 \mathrm{~Hz}\right), 3.71\left(\mathrm{~s}, 3 \mathrm{H}, \mathrm{OCH}_{3}\right)$, 4.21 (s, 2H, $\mathrm{CH}_{2} \mathrm{Ar}$ ), 4.39 (q, 2H, $\mathrm{CH}_{2}, J=8.2 \mathrm{~Hz}$ ), 5.1 (s, 2H, $\left.\mathrm{NCH}_{2} \mathrm{CO}\right), 7.17-7.99$ (m, 8H, ArH). ${ }^{13} \mathrm{C}-\mathrm{NMR}(100 \mathrm{MHz}$, DMSO- $\left.d_{6}\right) \delta$ ppm: 15.19, 36.11, 51.21, 56.09, 63.22, 115.67, $123.89,125.56,126.77,127.59,129.09,130.32,131.92,133.45$, 153.99, 156.82, 159.79, 171.01. MS: $m / z 352\left[\mathrm{M}^{+\cdot}\right](100 \%)$. Anal. Calcd for $\mathrm{C}_{20} \mathrm{H}_{20} \mathrm{~N}_{2} \mathrm{O}_{4}$ (352): C 68.18, H 5.68, N 7.95. Found: C 67.85, H 5.40, N 8.32.

Synthesis of 1-Hydrazinyl-4-(4-methoxybenzyl)phthalazine (11) A solution of $9(2.84 \mathrm{~g}, 0.01 \mathrm{~mol})$ and hydrazine hydrate $(0.5 \mathrm{~mL} ; 0.01 \mathrm{~mol})$ in ethanol $(30 \mathrm{~mL})$ was heated under reflux for $3 \mathrm{~h}$. The solid that separated after cooling was filtered off and recrystallized from ethanol.

Yield 90\%. mp 194-196 ${ }^{\circ}$ C. IR $(\mathrm{KBr}) v\left(\mathrm{~cm}^{-1}\right): 3379,3285$, $3147\left(\mathrm{NH}_{2}, \mathrm{NH}\right), 3048-2864(\mathrm{CH}), 1618(\mathrm{C}=\mathrm{N}),{ }^{1} \mathrm{H}-\mathrm{NMR}$ $\left(400 \mathrm{MHz}, \mathrm{DMSO}-d_{6}\right) \delta: 3.73\left(\mathrm{~s}, 3 \mathrm{H}, \mathrm{OCH}_{3}\right), 4.28(\mathrm{~s}, 2 \mathrm{H}$, $\mathrm{CH}_{2} \mathrm{Ar}$ ), 6.34 (s, 2H, NH $\mathrm{N}_{2}, \mathrm{D}_{2} \mathrm{O}$ exchangeable), 7.16-7.91 (m, $8 \mathrm{H}, \mathrm{ArH}), 9.19$ (s, 1H, NH, $\mathrm{D}_{2} \mathrm{O}$ exchangeable). ${ }^{13} \mathrm{C}-\mathrm{NMR}$ $\left(100 \mathrm{MHz}, \mathrm{DMSO}-d_{6}\right) \delta \mathrm{ppm}: 36.96,54.55,115.97,118.34$, 121.12 , 124.41, 127.44, 129.66, 130.54, 131.71, 133.11, 150.03, 156.82, 160.56. MS: $m / z 280\left[\mathrm{M}^{+\cdot}\right]$ (43.6\%). Anal. Calcd for $\mathrm{C}_{16} \mathrm{H}_{16} \mathrm{~N}_{4} \mathrm{O}$ (280): C, 68.57; H, 5.71; N 20.00. Found, C, 68.94; H, 6.05; N, 19.68 .

Synthesis of 2-(4-(4-Methoxybenzyl)-1-oxophthalazin2-yl)acetohydrazide (12) A solution of ester $\mathbf{1 0}(3.52 \mathrm{~g}$, $0.01 \mathrm{~mol})$ and hydrazine hydrate $(1.0 \mathrm{~mL}, 0.02 \mathrm{~mol})$ in ethanol $(30 \mathrm{~mL})$ was refluxed for $3 \mathrm{~h}$. The reaction mixture was concentrated and the obtained solid was filtered off and recrystal- lized from ethanol.

Yield $85 \%$. mp $252-254^{\circ} \mathrm{C}$. IR $(\mathrm{KBr}) v\left(\mathrm{~cm}^{-1}\right): 3350,3211$, $3130\left(\mathrm{NH}_{2}, \mathrm{NH}\right)$, 3050-2879 (CH), 1666, 1651 (CO), 1614 $(\mathrm{C}=\mathrm{N}) .{ }^{1} \mathrm{H}-\mathrm{NMR}\left(400 \mathrm{MHz}, \mathrm{DMSO}-d_{6}\right) \delta: 3.63\left(\mathrm{~s}, 3 \mathrm{H}, \mathrm{OCH}_{3}\right)$, 4.14 (s, 2H, $\mathrm{CH}_{2} \mathrm{Ar}$ ), 4.68 (s, 2H, $\mathrm{CH}_{2} \mathrm{CO}$ ), 5.55 (brs, $2 \mathrm{H}$, $\mathrm{NH}_{2}, \mathrm{D}_{2} \mathrm{O}$ exchangeable), 7.21-7.98 (m, 8H, ArH), $10.13(1 \mathrm{H}$, $\mathrm{NH}, \quad \mathrm{D}_{2} \mathrm{O}$ exchangeable). ${ }^{13} \mathrm{C}-\mathrm{NMR}\left(100 \mathrm{MHz}, \mathrm{DMSO}-d_{6}\right)$ $\delta$ ppm: 36.43, 56.33, 58.61, 116.27, 124.02, 125.88, 127.12, $128.34,129.45,130.72,131.77,133.32,134.21,152.87,155.15$, 159.02, 172.25. MS: $m / z 338\left[\mathrm{M}^{+}\right]$(29.6\%). Anal. Calcd for $\mathrm{C}_{18} \mathrm{H}_{18} \mathrm{~N}_{4} \mathrm{O}_{3}$ (338): C, 63.91; $\mathrm{H}$ 5.32; N, 16.57. Found: C, 64.22; H, 5.03; N, 16.20.

Synthesis of 1-(2-(Furan-2-ylmethylene)hydrazinyl)-4-(4methoxybenzyl)phthalazine (13) A solution of $11(2.8 \mathrm{~g}$, $0.01 \mathrm{~mol})$ and furfural $(0.96 \mathrm{~g}, 0.01 \mathrm{~mol})$ in ethanol $(20 \mathrm{~mL})$ was heated under reflux for $3 \mathrm{~h}$. The solid that separated after cooling was filtered off and recrystallized from ethanol. Yield 76\%. mp $140-142^{\circ} \mathrm{C}$. IR (KBr) $v\left(\mathrm{~cm}^{-1}\right)$ : $3190(\mathrm{NH})$, 3055-2878 (CH), $1614(\mathrm{C}=\mathrm{N}) .{ }^{1} \mathrm{H}-\mathrm{NMR}$ (400 MHz, DMSO$\left.d_{6}\right) \delta: 3.63\left(\mathrm{~s}, 3 \mathrm{H}, \mathrm{OCH}_{3}\right), 4.18\left(\mathrm{~s}, 2 \mathrm{H}, \mathrm{CH}_{2} \mathrm{Ar}\right), 6.39(\mathrm{~s}, 1 \mathrm{H}$, $-\mathrm{N}=\mathrm{CH}-$ ), 6.51 (m, 2H, H3, H4-furan) 7.13-8.10 (m, 9H, H5fur $+\mathrm{ArH}), 10.77\left(\mathrm{~s}, 1 \mathrm{H}, \mathrm{NH}, \mathrm{D}_{2} \mathrm{O}\right.$ exchangeable). ${ }^{13} \mathrm{C}-\mathrm{NMR}$ $\left(100 \mathrm{MHz}, \mathrm{DMSO}-d_{6}\right) \delta \mathrm{ppm}: 37.05,54.09,111.71,113.21$, $115.22,117.39,121.89,123.79,128.11,129.41,130.30,131.96$, $133.11,134.67,142.55,150.03,151.62,156.21,162.99 . \mathrm{MS}: \mathrm{m} / \mathrm{z}$ $358\left[\mathrm{M}^{+}\right]$(22.8\%). Anal. Calcd for $\mathrm{C}_{21} \mathrm{H}_{18} \mathrm{~N}_{4} \mathrm{O}_{2}$ (358): C, 70.39; H, 5.03; N, 15.64. Found: C, 70.69; H, 5.28; N, 13.00.

Synthesis of 6-(4-Methoxybenzyl)-3-methyl-[1,2,4]triazolo[3,4-a]phthalazine (14) A mixture of 11 (2.8g, $0.01 \mathrm{~mol})$ and acetic anhydride $(10 \mathrm{~mL})$ was heated for one hour on a water bath. Excess acetic anhydride was distilled of and solid was washed with water several times, then recrystallized from ethanol.

Yield $62 \%$. mp $162-164^{\circ} \mathrm{C}$. IR (KBr) $v\left(\mathrm{~cm}^{-1}\right)$ : 3052-2891 $(\mathrm{CH}), 1614(\mathrm{C}=\mathrm{N}) .{ }^{1} \mathrm{H}-\mathrm{NMR}\left(400 \mathrm{MHz}, \mathrm{DMSO}-d_{6}\right) \delta: 2.44(\mathrm{~s}$, $3 \mathrm{H}, \mathrm{CH}_{3}$ ), 3.65 (s, 3H, $\mathrm{OCH}_{3}$ ), 4.23 (s, 2H, $\mathrm{CH}_{2} \mathrm{Ar}$ ), 7.12-8.18 $(\mathrm{m}, 8 \mathrm{H}, \mathrm{ArH}) .{ }^{13} \mathrm{C}-\mathrm{NMR}\left(100 \mathrm{MHz}, \mathrm{DMSO}-d_{6}\right) \delta \mathrm{ppm}: 14.44$, $36.18,55.01,113.21,123.43,124.93,127.34,128.89,129.76$, 130.44, 131.71, 133.53, 134.67, 148.21, 156.21, 158.86. MS: $\mathrm{m} / \mathrm{z}$ $304\left[\mathrm{M}^{+\cdot}\right]$ (19.9\%). Anal. Calcd for $\mathrm{C}_{18} \mathrm{H}_{16} \mathrm{~N}_{4} \mathrm{O}$ (304): C, 71.05; H, 5.26; N, 18.42. Found: C, 70.76; H, 5.02; N, 18.70.

Synthesis of 6-(4-Methoxybenzyl)-[1,2,4]triazolo[3,4-a]phthalazine-3-thiol (15) A mixture of 11 (2.8 g, $0.01 \mathrm{~mol})$, carbon disulfide $(3.8 \mathrm{~g}, 0.05 \mathrm{~mol})$ and anhydrous potassium hydroxide $(0.5 \mathrm{~g})$ in absolute ethanol $(20 \mathrm{~mL})$ was refluxed on a water bath for $6 \mathrm{~h}$. The reaction mixture after cooling and concentration was poured into crushed ice. The solid that separated out was filtered off and recrystallized from dioxane.

Yield $60 \%$. mp $144-146^{\circ} \mathrm{C}$. IR (KBr) $v\left(\mathrm{~cm}^{-1}\right)$ : 3039-2874 $(\mathrm{CH}), 1614(\mathrm{C}=\mathrm{N}), 1271(\mathrm{C}=\mathrm{S}) .{ }^{1} \mathrm{H}-\mathrm{NMR}(400 \mathrm{MHz}, \mathrm{DMSO}-$ $\left.d_{6}\right) \delta: 3.62\left(\mathrm{~s}, 3 \mathrm{H}, \mathrm{OCH}_{3}\right), 4.26\left(\mathrm{~s}, 2 \mathrm{H}, \mathrm{CH}_{2} \mathrm{Ar}\right), 7.13-8.09(\mathrm{~m}$, $8 \mathrm{H}, \mathrm{ArH}), 11.96$ (s, 1H, SH, $\mathrm{D}_{2} \mathrm{O}$ exchangeable). ${ }^{13} \mathrm{C}-\mathrm{NMR}$ $\left(100 \mathrm{MHz}, \mathrm{DMSO}-d_{6}\right) \delta \mathrm{ppm}: 35.98,54.89,115.00,123.73$, $124.69,127.03,128.71,129.18,130.19,132.09,133.48,149.31$, 155.89, 158.18, 160.86. MS: $m / z 322\left[\mathrm{M}^{+}\right]$(19.9\%). Anal. Calcd for $\mathrm{C}_{17} \mathrm{H}_{14} \mathrm{~N}_{4} \mathrm{OS}$ (322): C, 63.35; H, 4.35; N, 17.39; S, 9.94. Found: C, 63.70; H, 4.08; N, 17.75; S, 10.30 .

Synthesis of 3-Hydrazinyl-6-(4-methoxybenzyl)-[1,2,4]triazolo[3,4-a]phthalazine (16) Hydrazine hydrate (1 mL, $0.02 \mathrm{~mol})$ was added to a solution of $\mathbf{1 5}(3.22 \mathrm{~g}, 0.01 \mathrm{~mol})$ in $25 \mathrm{~mL}$ ethanol. The reaction mixture was heated under reflux 
for $3 \mathrm{~h}$. The solid that separated after cooling and concentration was filtered off and recrystallized from ethanol.

Yield 54\%. mp $168-170^{\circ} \mathrm{C}$. IR $(\mathrm{KBr}) v\left(\mathrm{~cm}^{-1}\right): 3364,3260$, $3174\left(\mathrm{NH}_{2}, \mathrm{NH}\right), 3057-2891(\mathrm{CH}), 1614(\mathrm{C}=\mathrm{N}) .{ }^{1} \mathrm{H}-\mathrm{NMR}$ $\left(400 \mathrm{MHz}, \mathrm{DMSO}-d_{6}\right) \delta: 3.66\left(\mathrm{~s}, 3 \mathrm{H}, \mathrm{OCH}_{3}\right), 4.24(\mathrm{~s}, 2 \mathrm{H}$, $\mathrm{CH}_{2} \mathrm{Ar}$ ), 5.65 (s, 2H, $\mathrm{NH}_{2}, \mathrm{D}_{2} \mathrm{O}$ exchangeable), 7.05-8.06 (m, $8 \mathrm{H}, \mathrm{ArH}), 11.11$ (s, 1H, NH, $\mathrm{D}_{2} \mathrm{O}$ exchangeable). ${ }^{13} \mathrm{C}-\mathrm{NMR}$ $\left(100 \mathrm{MHz}, \mathrm{DMSO}-d_{6}\right) \delta \mathrm{ppm}: 35.21,55.44,115.55,123.61$, $124.18,127.44,128.65,129.39,130.21,132.00,133.66,148.21$, 156.56, 158.45, 159.98. MS: $m / z 320\left[\mathrm{M}^{+\cdot}\right]$ (30.2\%). Anal. Calcd for $\mathrm{C}_{17} \mathrm{H}_{16} \mathrm{~N}_{6} \mathrm{O}$ (320): C, 63.75; H, 5.00; N, 26.25. Found: C, 64.02; H, 5.29; N, 25.90.

Synthesis of the Hydrazones 17a-c A solution of acetohydrazide 12 (3.38 g, $0.01 \mathrm{~mol})$ and aromatic aldehydes namely, furan-2-carboxaldehyde, piperonal and 2-methoxybenzaldehyde $(0.01 \mathrm{~mol})$ in ethanol $(30 \mathrm{~mL})$ was refluxed for $3 \mathrm{~h}$. The reaction mixture allowed to cool and the obtained solid was filtered off and recrystallized from suitable solvent.

$N^{\prime}$-(Furan-2-ylmethylene)-2-(4-(4-methoxybenzyl)-1oxophthalazin-2(1H)-yl)acetohydrazide (17a)

Yield $74 \%$. mp $180-182^{\circ} \mathrm{C}$. Solvent (benzene). IR (KBr) $v\left(\mathrm{~cm}^{-1}\right): 3170(\mathrm{NH}), 3041-2896(\mathrm{CH}), 1680,1662(\mathrm{CO})$, $1614(\mathrm{C}=\mathrm{N}) .{ }^{1} \mathrm{H}-\mathrm{NMR}\left(400 \mathrm{MHz}, \mathrm{DMSO}-d_{6}\right) \delta: 3.72(\mathrm{~s}, 3 \mathrm{H}$, $\left.\mathrm{OCH}_{3}\right), 4.27\left(\mathrm{~s}, 2 \mathrm{H}, \mathrm{CH}_{2} \mathrm{Ar}\right), 5.02\left(\mathrm{~s}, 2 \mathrm{H}, \mathrm{CH}_{2} \mathrm{C}=\mathrm{O}\right), 6.16$ (s, 1H, N=CH), 6.48-6.77 (m, 2H, furH), 7.07-8.13 (m, 9H, ArH and C5-furan-H), 9.99 (s, 1H, NH, D $\mathrm{O}$ exchangeable). ${ }^{13} \mathrm{C}-\mathrm{NMR}\left(100 \mathrm{MHz}, \mathrm{DMSO}-d_{6}\right) \delta \mathrm{ppm}: 35.66,54.44,58.89$, $109.25,113.33,117.28,122.84,127.09,128.11,129.66,130.57$, $131.98,133.23,134.71,138.43,146.09,148.23,152.56,156.21$, 159.88, 168.99. MS: $\mathrm{m} / z$ 416 $\left[\mathrm{M}^{+\cdot}\right](13.5 \%)$. Anal. Calcd for $\mathrm{C}_{23} \mathrm{H}_{20} \mathrm{~N}_{4} \mathrm{O}_{4}$ (416): C, 66.35; H, 4.81; N, 13.46. Found: $\mathrm{C}$, 66.01; H, 5.06; N, 13.74 .

$N^{\prime}$ - (Benzo $[d] 1,3$ - dioxo-5 -ylmethylene-2-(4-(4methoxybenzyl)-1-oxophthalazin-2(1H)-yl)acetohydrazide (17b)

Yield $85 \%$. mp $186-188^{\circ} \mathrm{C}$. Solvent (ethanol). IR (KBr) v $\left(\mathrm{cm}^{-1}\right): 3186(\mathrm{NH}), 3052-2890(\mathrm{CH}), 1676,1665(\mathrm{CO}), 1611$ $(\mathrm{C}=\mathrm{N}) .{ }^{1} \mathrm{H}-\mathrm{NMR}\left(400 \mathrm{MHz}, \mathrm{DMSO}-d_{6}\right) \delta: 3.79\left(\mathrm{~s}, 3 \mathrm{H}, \mathrm{OCH}_{3}\right)$, 4.22 (s, 2H, $\left.\mathrm{CH}_{2} \mathrm{Ar}\right), 5.11\left(\mathrm{~s}, 2 \mathrm{H}, \mathrm{CH}_{2} \mathrm{C}=\mathrm{O}\right), 5.63(\mathrm{~s}, 2 \mathrm{H}, \mathrm{O}-$ $\left.\mathrm{CH}_{2}-\mathrm{O}\right), 6.25(\mathrm{~s}, 1 \mathrm{H}, \mathrm{N}=\mathrm{CH}), 7.14-8.18(\mathrm{~m}, 11 \mathrm{H}, \mathrm{ArH}), 10.11$ (s, $1 \mathrm{H}, \mathrm{NH}, \mathrm{D}_{2} \mathrm{O}$ exchangeable). MS: $m / z 470\left[\mathrm{M}^{+}\right]$(41.6\%). Anal. Calcd for $\mathrm{C}_{26} \mathrm{H}_{22} \mathrm{~N}_{4} \mathrm{O}_{5}$ (470): C, 66.38; H, 4.68; N, 11.91 . Found: C, 66.07; H, 4.97; N, 12.25.

2-(4-(4-Methoxybenzyl)-1-oxophthalazin-2(1H)-yl)- $N^{\prime}-(2-$ methoxybenzylidene)acetohydrazide (17c)

Yield $82 \%$. mp $192-194^{\circ} \mathrm{C}$. Solvent (toluene). IR (KBr) v $\left(\mathrm{cm}^{-1}\right): 3191(\mathrm{NH}), 3058-2895(\mathrm{CH}), 1679,1660(\mathrm{CO}), 1618$ $(\mathrm{C}=\mathrm{N}) .{ }^{1} \mathrm{H}-\mathrm{NMR}\left(400 \mathrm{MHz}, \mathrm{DMSO}-d_{6}\right) \delta: 3.62,3.79(\mathrm{~s}, 6 \mathrm{H}$, $\left.2 \mathrm{OCH}_{3}\right), 4.14\left(\mathrm{~s}, 2 \mathrm{H}, \mathrm{CH}_{2} \mathrm{Ar}\right), 5.06\left(\mathrm{~s}, 2 \mathrm{H}, \mathrm{CH}_{2} \mathrm{C}=\mathrm{O}\right), 6.31$ (s, $1 \mathrm{H}, \mathrm{N}=\mathrm{CH}), 7.10-8.08(\mathrm{~m}, 12 \mathrm{H}, \mathrm{ArH}), 10.32\left(\mathrm{~s}, 1 \mathrm{H}, \mathrm{NH}, \mathrm{D}_{2} \mathrm{O}\right.$ exchangeable). ${ }^{13} \mathrm{C}-\mathrm{NMR}\left(100 \mathrm{MHz}, \mathrm{DMSO}-d_{6}\right) \delta \mathrm{ppm}: 35.66$, $54.44,56.36,59.04,113.45,115.22,117.39,122.76,124.52$, $127.23,128.65,129.81,130.42,131.78,132.56,133.19,133.89$, $134.37,147.27,153.42,154.56,156.18,159.23,169.58 . \mathrm{MS}$ : $m / z 456\left[\mathrm{M}^{+\cdot}\right]$ (32.8\%). Anal. Calcd for $\mathrm{C}_{26} \mathrm{H}_{24} \mathrm{~N}_{4} \mathrm{O}_{4}$ (456): C, 68.42; H, 5.26; N, 12.28. Found: C, 68.09; H, 5.00; N, 12.60.

Synthesis of Compounds 18a and b A solution of 12 $(3.38 \mathrm{~g}, 0.01 \mathrm{~mol})$ and acetic anhydride or ethyl acetoacetate $(0.01 \mathrm{~mol})$ in ethanol $(30 \mathrm{~mL})$ was refluxed for $4 \mathrm{~h}$. The reaction mixture allowed to cool and the obtained solid was filtered off and crystallized from suitable solvent.
4-(4-Methoxybenzyl)-2-((5-methy-1,3,5-oxadiazol-2-yl)methyl)phthalazin-1(2H)-one (18a)

Yield $77 \%$. mp $172-174^{\circ} \mathrm{C}$. Solvent (benzene). IR (KBr) $v$ $\left(\mathrm{cm}^{-1}\right)$ : 3044-2876 (CH), $1672(\mathrm{CO}), 1619(\mathrm{C}=\mathrm{N}) .{ }^{1} \mathrm{H}-\mathrm{NMR}$ spectrum $\left(400 \mathrm{MHz}, \mathrm{DMSO}-d_{6}\right) \delta: 2.55\left(\mathrm{~s}, 3 \mathrm{H}, \mathrm{CH}_{3}\right), 3.73(\mathrm{~s}$, $\left.3 \mathrm{H}, \mathrm{OCH}_{3}\right), 4.14$ (s, 2H, $\left.\mathrm{CH}_{2} \mathrm{Ar}\right), 4.64\left(\mathrm{~s}, 2 \mathrm{H}, \mathrm{CH}_{2}\right), 7.07-8.23$ $(\mathrm{m}, \quad 8 \mathrm{H}, \mathrm{ArH}) .{ }^{13} \mathrm{C}-\mathrm{NMR}\left(100 \mathrm{MHz}, \mathrm{DMSO}-d_{6}\right) \delta \mathrm{ppm}$ : $22.06,35.32,50.44,56.11,113.31,122.22,125.66,128.32$, $129.14,130.59,131.85,132.77,134.37,154.39,156.55,159.23$, 161.19, 165.87. MS: $\mathrm{m} / \mathrm{z} 362\left[\mathrm{M}^{+}\right]$(29.9\%). Anal. Calcd for $\mathrm{C}_{20} \mathrm{H}_{18} \mathrm{~N}_{4} \mathrm{O}_{3}$ (362): C, 66.30; H, 4.97; N, 15.47. Found: C, $66.00 ; \mathrm{H}, 5.21 ; \mathrm{N}, 15.16$.

Synthesis of 4-(4-Methoxybenzyl)-2-((5-(2-oxopropyl)-1,3,5oxadiazol-2-yl)methyl)phthalazin-1(2H)-one (18b)

Yield 69\%. mp $188-190^{\circ} \mathrm{C}$. Solvent (dioxane). IR (KBr) $v\left(\mathrm{~cm}^{-1}\right)$ : 3050-2885 (CH), 1672, $1660(\mathrm{CO}), 1614(\mathrm{C}=\mathrm{N})$. ${ }^{1} \mathrm{H}-\mathrm{NMR}\left(400 \mathrm{MHz}, \mathrm{DMSO}-d_{6}\right) \delta: 2.01\left(\mathrm{~s}, 3 \mathrm{H}, \mathrm{COCH}_{3}\right), 3.74$ (s, 3H, $\left.\mathrm{OCH}_{3}\right), 3.92$ (s, 2H, $\left.\mathrm{CH}_{2} \mathrm{C}=\mathrm{O}\right), 4.11$ (s, 2H, $\left.\mathrm{CH}_{2} \mathrm{Ar}\right)$, 4.69 (s, 2H, $\left.\mathrm{CH}_{2}\right), 7.07-8.23(\mathrm{~m}, 8 \mathrm{H}, \mathrm{ArH}) . \mathrm{MS}: \mathrm{m} / z 404\left[\mathrm{M}^{+\cdot}\right]$ (18.7\%). Anal. Calcd for $\mathrm{C}_{22} \mathrm{H}_{20} \mathrm{~N}_{4} \mathrm{O}_{4}$ (404): C, 65.35; H, 4.95; $\mathrm{N}, 13.86$. Found: C, 65.71; H, 5.17; N, 14.14.

Synthesis of 2-((4-Acetyl-5-methyl-4H-pyrazol-3-yl)methyl)-4-(4-methoxybenzyl)-phthalazin-1(2H)-one (19) A solution of $12(3.38 \mathrm{~g}, 0.01 \mathrm{~mol})$ and acetyl acetone $(1.5 \mathrm{~g}$, $0.015 \mathrm{~mol})$ in ethanol $(30 \mathrm{~mL})$ was heated under reflux for $3 \mathrm{~h}$. The reaction mixture allowed to cool and the obtained solid was filtered off and crystallized from ethanol.

Yield $71 \%$. mp $178-180^{\circ} \mathrm{C}$. IR (KBr) $v\left(\mathrm{~cm}^{-1}\right)$ : 3051-2893 $(\mathrm{CH}), 1675,1663(\mathrm{CO}), 1620(\mathrm{C}=\mathrm{N}) .{ }^{1} \mathrm{H}-\mathrm{NMR} \quad(400 \mathrm{MHz}$, DMSO-d $\left.d_{6}\right) \delta: 2.12\left(\mathrm{~s}, 3 \mathrm{H}, \mathrm{COCH}_{3}\right), 2.79\left(\mathrm{~s}, 3 \mathrm{H}, \mathrm{CH}_{3}\right), 3.66(\mathrm{~s}$, $3 \mathrm{H}, \mathrm{OCH}_{3}$ ), 3.89 (s, 1H, pyrazole), 4.17 (s, 2H, $\left.\mathrm{CH}_{2} \mathrm{Ar}\right), 4.71$ (s, 2H, $\left.\mathrm{CH}_{2}\right), 7.10-8.26(\mathrm{~m}, 8 \mathrm{H}, \mathrm{ArH}) .{ }^{13} \mathrm{C}-\mathrm{NMR}(100 \mathrm{MHz}$, DMSO- $\left.d_{6}\right) \delta$ ppm: 15.06, 27.32, 35.86, 50.21, 53.34, 56.76, $115.01,122.88,125.76,128.44,129.21,130.34,131.96,132.89$, $134.76,144.99,154.23,156.12,159.14,161.19,198.01 . \mathrm{MS}:$ $m / z 402\left[\mathrm{M}^{+\cdot}\right]$ (16.9\%). Anal. Calcd for $\mathrm{C}_{23} \mathrm{H}_{22} \mathrm{~N}_{4} \mathrm{O}_{3}$ (402): C, 68.66; H, 5.47; N, 13.93. Found: C, 68.93; H, 5.70; N 14.29.

Synthesis of 2-((5-Mercapto-4H-1,2,4-triazol-3-yl)methyl)-4-(4-methoxybenzyl)phthalazin-1(2H)-one (20) A solution of $12(3.38 \mathrm{~g}, 0.01 \mathrm{~mol})$ and ammonium thiocyanate $(2.28 \mathrm{~g}, 0.03 \mathrm{~mol})$ in ethanol $(30 \mathrm{~mL})$ was heated under reflux for $3 \mathrm{~h}$. The solid that separated out after cooling was filtered off and crystallized from benzene.

Yield $61 \%$ mp $218-220^{\circ} \mathrm{C}$. IR $(\mathrm{KBr}) v\left(\mathrm{~cm}^{-1}\right)$ : $3179(\mathrm{NH})$, 3061-2892 (CH), 1678 (CO), $1614(\mathrm{C}=\mathrm{N}), 1265(\mathrm{C}=\mathrm{S})$. ${ }^{1} \mathrm{H}-\mathrm{NMR}\left(400 \mathrm{MHz}, \mathrm{DMSO}-d_{6}\right) \delta: 3.75\left(\mathrm{~s}, 3 \mathrm{H}, \mathrm{OCH}_{3}\right), 4.14(\mathrm{~s}$, $2 \mathrm{H}, \mathrm{CH}_{2} \mathrm{Ar}$ ), 4.57 (s, 2H, $\mathrm{CH}_{2}$ ), 7.04-8.22 (m, 8H, ArH), 10.76, 12.22, (2s, 2H, NH and, $\mathrm{SH} \mathrm{D}_{2} \mathrm{O}$ exchangeable). ${ }^{13} \mathrm{C}-\mathrm{NMR}$ $\left(100 \mathrm{MHz}, \mathrm{DMSO}-d_{6}\right) \delta$ ppm: $36.21,50.29,56.76,115.76$, $122.69,125.91,128.66,129.01,130.43,131.78,132.89,134.59$, $153.55,154.45,156.66,158.34,159.14$. MS: $m / z 379\left[\mathrm{M}^{+\cdot}\right]$ (10.4\%). Anal. Calcd for $\mathrm{C}_{19} \mathrm{H}_{17} \mathrm{~N}_{5} \mathrm{O}_{2} \mathrm{~S}$ (379): C, 60.16; H, 4.49; $\mathrm{N}, 18.47$; S, 8.44. Found: C, 60.50; H, 4.21; N, 18.09; S, 8.10.

Synthesis of N-(1,3-Dioxoisoindolin-2-yl)-2-(4-(4methoxybenzyl)-1-oxophthalazin-2(1H)-yl)-acetamide (21) A mixture of hydrazide $12(3.38 \mathrm{~g}, 0.01 \mathrm{~mol})$ and phthalic anhydride $(1.5 \mathrm{~g}, 0.01 \mathrm{~mol})$ was heated in an oil bath at $170^{\circ} \mathrm{C}$ for $1 \mathrm{~h}$. The reaction mixture was allowed to cool and the solid obtained was crystallized from ethanol.

Yield 58\%. mp 262-264 ${ }^{\circ} \mathrm{C}$. IR $(\mathrm{KBr}) v\left(\mathrm{~cm}^{-1}\right)$ : $3182(\mathrm{NH})$, 3051-2880 (CH), 1770, 1742, 1680, $1660(\mathrm{CO}), 1614(\mathrm{C}=\mathrm{N})$. 
${ }^{1} \mathrm{H}-\mathrm{NMR}\left(400 \mathrm{MHz}, \mathrm{DMSO}-d_{6}\right) \delta: 3.62\left(\mathrm{~s}, 3 \mathrm{H}, \mathrm{OCH}_{3}\right), 4.11$ (s, 2H, $\left.\mathrm{CH}_{2} \mathrm{Ar}\right), 4.59$ (s, 2H, $\left.\mathrm{CH}_{2}\right), 7.07-8.27$ (m, 12H, ArH), 12.23 (s, 1H, NH, D 2 exchangeable). ${ }^{13} \mathrm{C}-\mathrm{NMR}(100 \mathrm{MHz}$, DMSO- $\left.d_{6}\right) \delta$ ppm: $35.74,54.34,58.71,115.54,122.99,124.02$, $125.69,127.11,128.71,129.12,130.66,131.65,132.77,133.44$, $134.34,152.79,154.32,156.43,158.88,168.11$. MS: $m / z 468$ $\left[\mathrm{M}^{+\cdot}\right]$ (14.2\%). Anal. Calcd for $\mathrm{C}_{26} \mathrm{H}_{20} \mathrm{~N}_{4} \mathrm{O}_{5}$ (468): C, 66.67; H, 4.27; N, 11.97. Found: C, 66.34; H, 4.02; N, 12.31 .

Synthesis of 4-((4-((1-(4-Methoxyphenyl)ethylidene)amino)phenyl)sulfonyl)aniline (22) A mixture of dapsone (4,4'-sulfonyldianiline) $(2.48 \mathrm{~g}, 0.01 \mathrm{~mol})$ and 4-methoxyacetophenone $(1.50 \mathrm{~g}, 0.01 \mathrm{~mol})$ in $25 \mathrm{~mL}$ absolute ethanol was heated under reflux for $4 \mathrm{~h}$. The solid that separated out on cooling was filtered and crystallized from ethanol.

Yield 63\%. mp $176-178^{\circ} \mathrm{C}$ : IR $(\mathrm{KBr}) v\left(\mathrm{~cm}^{-1}\right)$ : 3430, 3321 $\left(\mathrm{NH}_{2}\right), 1610(\mathrm{C}=\mathrm{N}), 1160(\mathrm{~S}=\mathrm{O}) .{ }^{1} \mathrm{H}-\mathrm{NMR}(400 \mathrm{MHz}, \mathrm{DMSO}-$ $\left.d_{6}\right) \delta: 2.11\left(\mathrm{~s}, 3 \mathrm{H}, \mathrm{CH}_{3}\right), 3.74\left(\mathrm{~s}, 3 \mathrm{H}, \mathrm{OCH}_{3}\right), 6.45\left(\mathrm{~s}, 2 \mathrm{H}, \mathrm{NH}_{2}\right.$, $\mathrm{D}_{2} \mathrm{O}$ exchangeable), 7.10-8.11 (m, 12H, 3 ArH). MS: $m / z 380$ $\left[\mathrm{M}^{+}\right]$(33.3\%). Anal. Calcd for $\mathrm{C}_{21} \mathrm{H}_{20} \mathrm{~N}_{2} \mathrm{O}_{3} \mathrm{~S}$ (380): C, 66.32; H, 5.26; N, 7.37; S, 8.42. Found: C, 66.66; H, 5.55; N, 7.06; S, 8.07 .

Synthesis of 4-(4-Methoxybenzyl)-N-(4-((4-((1-(4-methoxyphenyl)ethylidene)amino)phenyl)-sulfonyl)phenyl)phthalazin-1-amine (23) Chlorophthalazine derivative 9 $(2.84 \mathrm{~g}, 0.01 \mathrm{~mol})$ and the Schiff base $22(3.80 \mathrm{~g}, 0.01 \mathrm{~mol})$ were dissolved in $30 \mathrm{~mL}$ absolute ethanol and $0.5 \mathrm{~mL}$ pyridine was added. The reaction mixture was heated under reflux for $6 \mathrm{~h}$. The resulting mixture was cooled and poured onto ice/water. The solid that separated out was filtered, washed with water, air-dried and crystallized from ethanol

Yield 58\%. mp 270-272 ${ }^{\circ} \mathrm{C}$ : IR $(\mathrm{KBr}) v\left(\mathrm{~cm}^{-1}\right): 3230(\mathrm{NH})$, $1619(\mathrm{C}=\mathrm{N}), 1155(\mathrm{~S}=\mathrm{O}) .{ }^{1} \mathrm{H}-\mathrm{NMR}\left(400 \mathrm{MHz}, \mathrm{DMSO}-d_{6}\right) \delta$ : $2.17\left(\mathrm{~s}, 3 \mathrm{H}, \mathrm{CH}_{3}\right), 3.67,3.84\left(2 \mathrm{~s}, 6 \mathrm{H}, 2 \mathrm{OCH}_{3}\right), 4.21(\mathrm{~s}, 2 \mathrm{H}$, $\left.\mathrm{CH}_{2} \mathrm{Ar}\right), 7.09-8.08(\mathrm{~m}, 20 \mathrm{H}, \mathrm{Ar}-\mathrm{H}), 9.94\left(\mathrm{~s}, 1 \mathrm{H}, \mathrm{NH}, \mathrm{D}_{2} \mathrm{O}\right.$ exchangeable). ${ }^{13} \mathrm{C}-\mathrm{NMR}\left(100 \mathrm{MHz}, \mathrm{DMSO}-d_{6}\right) \delta$ ppm: 22.79 , $36.46,55.11,57.52,113.89,114.12,115.33,117.52,120.87$, $123.31,124.19,127.49,128.99,129.62,130.51,131.68,132.23$, $132.75,133.43,135.32,136.32,138.7,144.83,147.64,153.91$, 155.29, 163.88, 165.22, 167.31. MS: $m / z 628\left[\mathrm{M}^{+}\right](13.2 \%)$. Anal. Calcd for $\mathrm{C}_{37} \mathrm{H}_{32} \mathrm{~N}_{4} \mathrm{O}_{4} \mathrm{~S}(628)$ : C, 70.70; H, 5.10; N, 8.91; S, 5.10. Found: C, 71.01; H, 5.37; N, 9.32; S, 5.43.

Synthesis of $N$-(4-(4-Methoxybenzyl)phthalazin-1-yl)$\mathrm{N}$-(4-((4-((1-(4-methoxyphenyl)-ethylidene)amino)phenyl)sulfonyl)phenyl)furan-2-carboxamide (24) A mixture of compound $23(3.14 \mathrm{~g}, 0.005 \mathrm{~mol})$ and 2-furoyl chloride $(0.65 \mathrm{~g}$, $0.005 \mathrm{~mol}$ ) was refluxed in $30 \mathrm{~mL}$ of dry pyridine for $3 \mathrm{~h}$. The excess solvent was distilled off and the reaction solution was cooled, then poured into crushed ice with frequent stirring leaving a crude product which was filtered off, washed with water, dried and crystallized from ethanol.

Yield 78\%. mp 284-286 ${ }^{\circ} \mathrm{C}$. IR $(\mathrm{KBr}) v\left(\mathrm{~cm}^{-1}\right)$ : $1674(\mathrm{C}=\mathrm{O})$, $1602(\mathrm{C}=\mathrm{N}), 1157(\mathrm{~S}=\mathrm{O}) .{ }^{1} \mathrm{H}-\mathrm{NMR}\left(400 \mathrm{MHz}, \mathrm{DMSO}-d_{6}\right)$ $\delta: 2.14\left(\mathrm{~s}, 3 \mathrm{H}, \mathrm{CH}_{3}\right), 3.70,3.85\left(2 \mathrm{~s}, 6 \mathrm{H}, 2 \mathrm{OCH}_{3}\right), 4.16(\mathrm{~s}, 2 \mathrm{H}$, $\left.\mathrm{CH}_{2} \mathrm{Ar}\right), 6.82-8.23\left(\mathrm{~m}, 23 \mathrm{H}, \mathrm{ArH}\right.$ and furan-H). ${ }^{13} \mathrm{C}-\mathrm{NMR}$ $\left(100 \mathrm{MHz}, \mathrm{DMSO}-d_{6}\right) \delta$ ppm: 22.48, 36.05, 55.82, 58.49, $112.62,113.45,114.78,116.56,117.72,120.61,122.24,123.60$, $124.29,125.91,127.48,128.58,129.87,130.25,131.54,132.33$, $132.89,134.67,136.34,140.78,142.78,146.31,147.42,149.24$, 153.89, 156.32, 158.68, 161.78, 163.31, 166.39. MS: $\mathrm{m} / \mathrm{z} 722$ $\left[\mathrm{M}^{+}\right]$(25.7\%). Anal. Calcd for $\mathrm{C}_{42} \mathrm{H}_{34} \mathrm{~N}_{4} \mathrm{O}_{6} \mathrm{~S}$ (722): C, 69.81; $\mathrm{H}$, 4.71; N, 7.76; S 4.43. Found: C, 70.14; H, 5.00; N, 8.08; S, 4.09.

\section{Conclusion}

In this paper, several new heterocyclic compounds that contain a phthalazine and phthalazinone moieties were synthesized using simple methods. The structures of the newly synthesized compounds were elucidated by different spectral methods and they were tested for their antimicrobial activities. Most of these compounds showed promising activities against different bacteria and fungi strains.

Acknowledgment The authors would like to express their deep appreciation for Prof. Dr. Abd-El-Galil Amr, Pharmaceutical Chemistry Department, College of Pharmacy, King Saud University, Saudi Arabia for his efforts in doing ${ }^{13} \mathrm{C}-\mathrm{NMR}$.

Conflict of Interest The authors declare no conflict of interest.

\section{References}

1) Jain R. P., Vederas J. C., Bioorg. Med. Chem. Lett., 14, 3655-3658 (2004).

2) Strappaghetti G., Brodi C., Giannaccini G., Betti L., Bioorg. Med. Chem. Lett., 16, 2575-2579 (2006).

3) Li W., Li H., Li Z., Tetrahedron Lett., 51, 5448-5450 (2010).

4) El-Feky S. A. H., Abd El-Fattah H. A., Osman N. A., Imran M., Zedan M. N., J. Chem. Pharm. Res., 7, 1154-1166 (2015).

5) Eldehna W. M., Ibrahim H. S., Abdel-Aziz H. A., Farrag N. N., Youssef M. M., Eur. J. Med. Chem., 89, 549-560 (2015).

6) Zhang S., Zhao Y., Liu Y., Chen D., Lan W., Zhao Q., Dong C., Xia L., Gong P., Eur. J. Med. Chem., 45, 3504-3510 (2010).

7) Wasfy A. F., Aly A. A., Behalo M. S., Mohamed N. S., Chem. Process Eng. Res., 10, 20-32 (2013).

8) Sherif Y. E., Hosny N. M., Med. Chem. Res., 23, 2536-2542 (2014).

9) Yaseen S., Bashir R., Ovais S., Rathore P., Samim M., Javed K., J. Enzyme Inhib. Med. Chem., 29, 362-366 (2014).

10) Bian M., Deng X. Q., Gong G. H., Wei C. X., Quan Z. S., J. Enzyme Inhib. Med. Chem., 28, 792-800 (2013).

11) Demirayak S., Karaburun A. C., Beis R., Eur. J. Med. Chem., 39, 1089-1095 (2004).

12) Johnsen M., Rehse K., Pertz H., Stasch J. P., Bischoff E., Arch. Pharm., 336, 591-597 (2003).

13) Olmo E., Armas M. G., López-Pérez J., Ruiz G., Vargas F. Giménez A., Deharo E., San Feliciano A., Bioorg. Med. Chem. Lett., 11, 2755-2757 (2001).

14) Bayoumi W. A., Barghash A. M., Gineinah M. M., Massoud M. A., Abdelal A. M., Der Phar. Chem., 6, 89-102 (2014).

15) Sherif Y. E., Gouda M. A., El-Asmy A. A., Med. Chem. Res., 24, 3853-3862 (2015)

16) Abouzid K. A. M., Khalil N. A., Ahmed E. M., Med. Chem. Res., 22, 1057-1064 (2013).

17) Deshpande S. R., Ghongade A. M., Pai V. K., Indian J., Pharm. Educ. Res., 44, 1-7 (2010).

18) Khalil N. A., Ahmed E. M., Elshihawy H. A., Zaitone S. A., Arch. Pharm. Res., 36, 671-683 (2013).

19) Leiro J. M., Alvarez E., Arranz J. A., Cano E., Orallo F., Int. Immunopharmacol., 4, 163-177 (2004).

20) Scheffler G., Engel J., Kutscher B., Sheldrick W. S., Bell P., Arch. Pharm., 321, 205-208 (1988).

21) Kador P. F., Kinoshita J. H., Sharpless N. E., J. Med. Chem., 28, 841-849 (1985)

22) Mylari B. L., Larson E. R., Beyer T. A., Zembrowski W. J., Aldinger C. E., Dee M. F., Siegel T. W., Singleton D. H., J. Med. Chem., 34, 108-122 (1991).

23) El-Shamy I. E., Abdel-Mohsen A. M., Alsheikh A. A., Fouda M. G., Al-Deyab S. S., El-Hashash M. A., Jancar J., Dyes Pigments, 113, 357-371 (2015). 
24) El-Hashash M. A., Guirguis D. B., Abd El-Wahed N. A., Kadhim M. A., Int. J. Sci. Res., 3, 1701-1706 (2014).

25) Pathak S., Debnath K., Hossain S. T., Mukherjee S. K., Pramanik A., Tetrahedron Lett., 54, 3137-3143 (2013).

26) Abd El-Wahab A. H. F., Mohamed H. M., El-Agrody A. M., ElNassag M. A., Bedair A. H., Pharmaceuticals, 4, 1158-1170 (2011).

27) Azab M. E., Amr A. E., Russ. J. Gen. Chem., 85, 1513-1521 (2015)

28) Azab M. E., Amr A. E., Al-Omar M. A., Russ. J. Gen. Chem., 85, 1952-1958 (2015).

29) Azab M. E., Rizk S. A., Amr A. E., Molecules, 20, 18201-18218 (2015)

30) El-Hashash M. A., Rizk S. A., Egypt. J. Chem., 54, 411-422 (2011).

31) El-Hashash M. A., Darwish K. M., Rizk S. A., El-Bassiouny F. A., Glob. J. Health Sci., 4, 174-183 (2012).

32) El-Shenawy A. L., Chem. Pap., 58, 205-208 (2004).

33) del Olmo E., Armas M. G., López-Pérez J. L., Muñoz V., Deharo E., San Feliciano A. S., Bioorg. Med. Chem. Lett., 11, 2123-2126
(2001)

34) Abd Alla M. S., Hegab M. I., Abo Taleb N. A., Hasabelnaby S. M. Goudah A., Eur. J. Med. Chem., 45, 1267-1277 (2010).

35) El-Hashash M. A., Rizk S. A., El-Bassiouny F. A., Darwish K. M., Glob. J. Health Sci., 4, 162-173 (2012).

36) Abd El-Ghaffar N. F., Mohamed M. A., Ghanem H. M., Zaki H. M., Journal of American Science, 7, 771-781 (2011).

37) El-Hashash M. A., Soliman A. Y., El-Shamy I. E., Turk. J. Chem., 36, 347-366 (2012).

38) Kandile N. G., Zaky H. T., Mohamed M. I., Mohamed H. M., Bull. Korean Chem. Soc., 31, 3530-3538 (2010).

39) El-Hashash M. A., Guirguis D. B., Abd El-Wahed N. A. M., Kadhim M. A., J. Chem. Eng. Process Technol., 5, 1-6 (2014).

40) Wells A. F., "Structural Inorganic Chemistry," 5th ed., Oxford University Press, Oxford, UK, 1984

41) Cheesbrough M., "District Laboratory Practice in Tropical Countries," Part 2. Cambridge University Press, Cambridge, UK, 2000. 